\title{
Time-Varying Pass-Through from Import Prices to Consumer Prices: Evidence from an Event Study with Real-Time Data
}

Marlene Amstad and Andreas M. Fischer

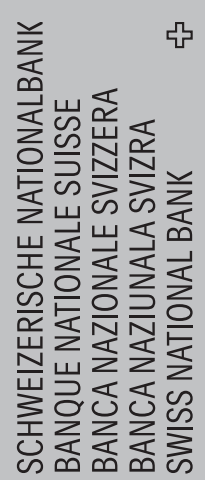


The views expressed in this paper are those of the author(s) and do not necessarily represent those of the Swiss National Bank. Working Papers describe research in progress. Their aim is to elicit comments and to further debate.

ISSN $1660-7716$

๑ 2006 by Swiss National Bank, Börsenstrasse 15, P.0. Box, CH-8022 Zurich 


\title{
Time-Varying Pass-Through from Import Prices to Consumer Prices: Evidence from an Event Study with Real-Time Data
}

\author{
Marlene Amstad ${ }^{1}$ \\ Andreas M. Fischer ${ }^{2}$
}

February 2006

\begin{abstract}
This paper analyzes the pass-through from import prices to CPI inflation in real time. Our strategy follows an event-study approach, which compares inflation forecasts before and after import price releases. Inflation forecasts are modelled using a dynamic factor procedure that relies on daily panels of Swiss data. We find strong evidence that monthly import price releases provide important information for CPI inflation forecasts and that the behavior of updated forecasts is consistent with a time-varying pass-through. The robustness of this latter result is underpinned in two ways: an alternative CPI measure that excludes price components subject to administered pricing and panels capturing different levels of information breadth. Besides implying a time-varying pass-through, our empirical findings cast doubt on a prominent role of sticky prices for the low pass-through findings.
\end{abstract}

Keywords: Common Factors, Pass-Through, Daily Panels JEL Classification Number: E52, E58

${ }^{1}$ Swiss National Bank, Postfach, 8022 Zurich, Switzerland telephone (+41 1) 63137 29, FAX (+41 1) 6313901

e-mail: marlene.amstad@snb.ch

${ }^{2}$ Swiss National Bank and CEPR, Postfach, 8022 Zurich, Switzerland telephone (+41 1) 63132 94, FAX (+41 1) 6318172

e-mail: andreas.fischer@snb.ch

* The authors would like to thank Philippe Bacchetta, Yu-chin Chen, Marc Giannoni, Matthias Lutz, Jonathan McCarthy, and Robert Rich for helpful discussion and comments and to acknowledge the software developed by Forni, Hallin, Lippi, and Reichlin (2000). Tobias Grässli provided valuable assistance in data support. The views expressed here are those of the authors, and do not necessarily reflect the position of the Swiss National Bank. 


\section{Introduction}

One research path taken to explain the reduced pass-through phenomena of the 1990 s is to link the incomplete pass-through to the inflation regime. ${ }^{1}$ Taylor (2000) initiated the discussion by arguing that the exchange rate passthrough into import prices matters only when there are persistent exchange rate changes. These tend to be muted in an environment where inflation is low and monetary policy is credible, because the pricing power of firms is diminished in a low inflation regime. Taylor's (2000) model attempts to capture the main unifying elements of an emerging literature that introduce nominal rigidities and market imperfections into a dynamic general equilibrium model with well-specified microfoundations.

This paper contributes in three ways to the recent literature by Taylor (2000), Devereux and Yetman (2002), and others that model endogenously the exchange rate pass-through to the monetary policy regime. First, the analysis presents a new estimation strategy that allows the pass-through to be interpreted in a time-varying manner. The empirical methodology is similar in spirit to event study procedures used in empirical finance, see

\footnotetext{
${ }^{1}$ See McCarthy (2000) for time series evidence. Bailliu and Fuji (2004), Choudhri and Hakura (2001), and Gagon and Ihrig (2004) provide cross-country analysis.
} 
MacKinlay (1997) or Khotari and Warner (2005) for an overview. The timevarying estimation procedure allows us to determine whether changing passthrough estimates arise also for within a low-inflation regime. If large random fluctuations in the monthly pass-through estimates are observed in a low inflation regime, then this is inconsistent with Taylor's (2000) argument that firms will choose a higher frequency of price adjustment because of higher average inflation.

A second contribution is to consider the role of information breadth in pass-through estimates using real-time data. The estimation procedure based on dynamic common factors with daily panels is able to encompass alternative information sets that are consistent with CPI inflation, asset price inflation, and core inflation. Previous empirical studies highlighted particular variables at the quarterly or annual frequency. Our intention is to mimic actual data environments used by policymakers and with this understand the data panel's influence on the pass-through estimates and in the policy setting for inflation forecasts.

A third extension considers whether price stickiness is responsible for low pass-through estimates. The empirical analysis is carried out using the Consumer Price Index (CPI) and an adjusted price index defined as CPI minus 
administrative prices. The choice of the latter index is guided by the empirical evidence in Bils and Klenow (2004) on the frequency of price changes. The adjusted index is used as a robustness check to determine whether nominal price rigidity captured through administrative pricing has any bearing for the pass-through. The assumption of nominal price rigidities, say through Calvo (1983) or Taylor (1980) pricing behavior, is used by Devereux and Yetman (2002) to explain a regime dependent pass-through. ${ }^{2}$

The analysis examines the monthly information stemming from import price releases on inflation forecasts. The use of inflation forecasts in estimating the pass-through is motivated by theoretical models that link an endogenous pass-through to a forward-looking inflation equation. Because the focus is on import price releases, our measure of the pass-through is from import prices to consumer prices. The decision not to work with the traditional definition of the pass-through from exchange rates to import prices does not stem from the prior that the information content of import prices is superior to the exchange rate. ${ }^{3}$ Rather the motivation rests on the fact that

\footnotetext{
${ }^{2}$ Price rigidity is frequently used in new open economy models, see Lane (2001). Specific examples include Chari et al. (1998) and Kollmann (1997).

${ }^{3}$ Most theoretical models give a simultaneous link between import and consumer prices. Bacchetta and van Wincoop (2003) and Engel (2002) are an exception.
} 
the import price index is not subject to expectations biases as is the exchange rate. By examining the information content of import price releases, it is not necessary to worry about modelling and disentangling anticipatory effects.

The empirical strategy involves the following steps. The first step generates inflation forecasts based on daily panels that encompass real-time information from financial variables and data releases. The forecasting exercise relies on the dynamic common factor procedure by Forni et al. (2000) and builds on earlier work by Amstad and Fischer (2004, 2005). The next step constructs the forecast innovation stemming from the one-day difference in the inflation forecast before and after the monthly release in import prices. The last step tests whether the direction of the forecast innovations is consistent with the direction of the monthly changes in import prices.

The empirical analysis is conducted for Switzerland: a small open economy that devotes considerable attention to exchange rate fluctuations in its monetary policy decisions. The empirical sample is from 1993:5 to 2005:5. During this period, CPI inflation averaged below $1 \%$ and the nominal effective exchange rate fluctuated in the order of $+/-15 \%$. These characteristics of low average inflation together with modest fluctuations in the exchange rate fit many OECD economies for the most recent decade. 
The time-varying analysis on the information content of import price releases offers three new empirical findings. First, the pass-through from import prices to consumer prices is on average small - a result reconfirmed with real-time data. However, we find this holds only on average, because the pass-through estimates exhibit considerable time-varying behavior for a low inflation regime. Second, the pass-through estimates are highly dependent on the information breadth of the panels. The median estimate of the passthrough is largest for the narrowest information panel and smallest for the largest information panel. Third, the responses of rigid and more flexible price measures to import price information are statistically equivalent. This finding, at least for a low inflation regime, does not support the assumption of nominal frictions used frequently in new open economy models.

The paper is organized as follows. Section 1 discusses the data: the selected sample, the price indexes, and the daily panels used to generate the inflation forecasts. Section 2 first motivates the use of inflation forecasts in our estimation strategy. Next, it defines the empirical strategy to identify the monthly pass-through from import prices to CPI inflation. Section 3 presents the main empirical findings. Section 4 offers concluding remarks. 


\section{Real-Time Data Panels with Import Prices}

This section describes the sample defining the low inflation regime, import prices, consumer price indexes, and four panels used to project the inflation forecasts. All economic series used to construct the panels are taken from the Swiss National Bank's (SNB) data bank. Appendix 1 discusses variable transformations.

\section{The Sample}

The panels, which are discussed separately below, are from 1993:5 to 2005:5. The empirical procedure requires a balanced panel at sample start but allows an unbalanced panel at sample end. This enables us to capture real-time information by using daily updated panels to estimate the passthrough. The starting date, 1993:5, is chosen for the following reasons. First, a large number of series do not go further back than 1990:1. Second, the date, 1993:5, coincides with a major revision in the CPI index and the beginning of the import price series. Third, the period 1990:1 to 1993:4 is excluded, because during this brief phase Swiss inflation averaged 5.5\% and is not representative of the low inflation regime sought to test the responsiveness of inflation forecasts to information from import price releases. ${ }^{4}$

\footnotetext{
${ }^{4}$ Officially, the SNB does not recognize low or high inflation regimes. Structural break
} 
The period 1993:5 to 2003:10 represents the estimation window used to generate the first inflation forecast. The forecasts based on daily panels before and after the release dates of the import prices begin 2003:12. The release dates for import prices for month $t$ fall generally during the third week of month $t+1$. With this setup, the forecast innovations centered around 18 import price releases are examined for the period 2003:12 to 2005:5.

The limited number of import price releases considered in the analysis is restricted by the size of the real-time data set. The sample from 2003:12 to 2005:5 is representative of the post-1993 low inflation regime marked by no abrupt changes in Swiss monetary policy and moderate fluctuations in the Swiss franc. ${ }^{5}$ Fischer (2002) offers a discussion of Swiss monetary and Swiss franc behavior covering the 1991-2002 period. $^{6}$

Import Prices

tests on inflation persistence are, however, one means for identifying regime shifts. Tests of this sort by Levin and Piger (2002) find a break in Swiss CPI in the second quarter of 1993.

${ }^{5}$ Implicitly, we assume that changes in the composition of the import price index have no influence on the pass-through. Campa and Goldberg (2002) test this assumption for a longer sample.

${ }^{6}$ The Swiss franc floats freely and enters as an information variable in the SNB's inflation forecast. 
The data block defining import prices are 16 price indexes: total imports, 12 components of finished products, agricultural goods, consumption goods, and semi-processeded goods. Agricultural products (2.52\%) along with the 12 indexes of finished products (95.86\%) make up $98.38 \%$ of the total import price index. Consumption and semi-process goods are alternative indexes to those defined by finished products and agricultural goods. They make up $53.87 \%$ of the total import price index. The remaining categories are excluded because of their short sample.

To understand how the pass-through behaves in a low inflation regime, Figure 1 depicts three indexes: the CPI, the total import price index, and nominal effective exchange rate (hereafter, the trade weighted index (TWI)). The series are normalized to unity for May 1993 and the TWI is inverted so that the increase in the inverse corresponds with an appreciation of the Swiss franc. Three features are noteworthy. First, while $70 \%$ of Swiss imports come from EU countries, it is not evident that the euro's introduction in 1999 had any profound bearing on the profile of the three series. ${ }^{7}$ Second, the pass-

\footnotetext{
${ }^{7}$ The large import share from the euro area represents a drawback in using exchange rates as an information block in estimating the pass-through. If a country's trade patterns are highly concentrated with a single country or currency union, the sought after crosssectional information is limited.
} 
through between import prices and the TWI varies over time. From May 1993 to November 1996, import prices react marginally and with a lag to the $15 \%$ appreciation in the TWI. Thereafter from December 1996 to May 2000, the relationship appears to be tighter because the fluctuations of the two series move in sync. After June 2000, import prices do not react fully to the $10 \%$ appreciation in the TWI.

A third feature of Figure 1 is the non-existent pass-through between the TWI and the CPI: a static regression of the CPI on a constant and the TWI for 1993:5 to 2005:4 yields an insignificant coefficient of 0.037. The zero pass-through between the exchange rate and CPI inflation for select episodes reconfirms the empirical results of Cunningham and Haldane (2000) and underpins the theoretical assumption of pricing to market used by Betts and Devereux (1996) and others.

Figure 2 presents information on the monthly change in total import prices and CPI from 2003:11 to 2005:4. The transformed variables are 18 release dates to be analyzed in section 3 . Figure 2 shows that the directional movements in the price indexes are tighter in log differences than in levels. ${ }^{8}$

\footnotetext{
${ }^{8} \mathrm{~A}$ simple OLS regression of the (ln) monthly difference in CPI on the (ln) monthly difference in the TWI yields an insignificant coefficient of 0.15 for this period.
} 


\section{The Price Indexes}

Two price indexes are used to generate the inflation forecasts for CPI and for CPI minus administered prices. The latter measure is motivated by our interest to determine if there are quantitative differences in pass-through behavior between a price measure that entails elements of price rigidity captured through administrative pricing in headline CPI inflation and the constructed measure that excludes those elements. The selection of the excluded items is based on the following criteria: 12 measures are recognized by Switzerland's statistical agency (BfS) to be subject to administrative pricing and four further series linked to public medical expenses were chosen by the authors following the empirical results of Bils and Klenow (2004). ${ }^{9}$ The excluded components from the CPI basket are health care (medical care, drugs, hospital care, dental treatment, and total); public transport (train, public transport regional); leisure, activities, culture (cinema, radio and TV concessions,

\footnotetext{
${ }^{9}$ Bils and Klenow (2004) find that the frequency of price changes varies considerably across categories. They exploit this variation to ask how inflation for flexible price goods (goods with frequent changes in individual prices) differs from inflation for sticky price goods (those displaying infrequent price changes). In particular, they find that prices for medical and entertainment in the United States exhibit the most extreme form of price stickiness.
} 
other services, sport and leisure activity, sporting event, theater and concert, and mountain railways and lifts); and education (continuing education and total education). The sum of the excluded elements have a weight of $20.87 \%$ when measured against the 2005 CPI basket. ${ }^{10}$

Figure 3 plots the CPI $\left(p^{s}\right)$ and CPI minus administrative prices $\left(p^{f}\right)$ for the full sample. Hereafter, the superscript $s$ denotes sticky prices and $f$ for flexible prices. The two series are normalized to unity at sample start. The two series move closely together with CPI minus administered prices exhibiting slightly greater fluctuations. Although the two series appear similar, Figure 4 shows for the sample from 2003:11 to 2005:4 that $\Delta p^{f}$ is slightly more volatile (measured by the standard deviation 0.28 versus 0.20 ) than $\Delta p^{s}$. Bils and Klenow (2004) find that this property also holds for U.S. data.

\section{The Data Panels}

The analysis considers four panels, $\{P(1), \cdots, P(4)\}$, to project the CPIinflation forecasts. The panels are constructed with the explicit intention where the narrowest panel, i.e., the least number of cross-sectional variables,

\footnotetext{
${ }^{10}$ In Bils and Klenow (2004), the $20 \%$ most sticky prices of the CPI change every 10 months or less frequent. However, the Bils and Klenow's BLS data suggests much more frequent price adjustment than has been found in other studies.
} 
captures the largest possible pass-through responses for inflation forecasts. There are two considerations behind this conjecture. The first is due to data type: the narrow panel includes only price variables that are subject to some form of competitive pricing. Since CPI minus administrative prices in Figure 3 exhibits greater fluctuations, it is expected that inflation forecasts conditional on the narrower panel should react stronger to new information in import prices. The second motive concerns information breadth. It is most likely that large information sets contain overlapping information with respect to import price releases (i.e., real trade volume that is released one week prior to the import prices). This suggests that the impact of import prices on CPI inflation could be mitigated once larger information sets are considered. The broader panels, which attempt to replicate the data-rich environment that central bankers operate under, are composed of nominal variables subject to administrative and competitive price settings together with real and foreign variables.

Table 1 shows the breakdown of the 449 series, their frequency, and their transformations. There are 27 financial variables at the daily frequency and 422 nominal and real variables at the monthly frequency. ${ }^{11}$ This data envi-

\footnotetext{
${ }^{11}$ The monthly series are generally not revised in Switzerland, apart from the monthly
} 
ronment defines the largest information set of the four panels used to forecast inflation measured by CPI and CPI minus administrative prices. The first panel, labelled $P(1)$, has 177 price series. It includes the CPI index, 16 import price indexes, and CPI's subcomponents that are not subject to administrative pricing. The information space is constructed so that it is consistent with our CPI index that excludes non administrative prices.

The second panel, $P(2)$, captures the information space defined by the CPI and has 193 variables. More formally, $P(2)$ is $P(1)$ plus the 16 administrative components (i.e., rows 178 to 193 in Table 1). In terms of the inflation measures, the information space for $P(2)$ is consistent with the time series study by the BIS (2005). They examine the behavior of import price shocks on CPI inflation to make statements about the pass-through.

The third panel, $P(3)$, has 269 variables (i.e., rows 1 to 169 in Table 1). It is defined as $P(2)$ plus the nominal variables listed in Table 1 . The inflation forecasts based on $P(3)$ may be viewed as a proxy for core inflation, because other nominal variables, such as money, credit, exchange rates, oil credit and monetary aggregates. This has the advantage that our inflation forecasts are not seriously contaminated by revision errors. Vintage errors are a serious problem for select quarterly series in Switzerland. 
prices, stock prices, and interest rates, are used to predict inflation. Apart from the exclusion of real-estate variables from $P(3)$, the estimated inflation measure may also be interpreted as in Goodhart and Hofmann (2000) as an index that captures inflationary pressures stemming from asset prices.

The fourth panel, $P(4)$, encompasses $P(3)$ plus the real elements in Table 1. Inflation forecasts based on this panel embody the widest concept of core inflation that is consistent with the Phillips curve. In this case, measures of real and nominal activity are used to predict inflation. Stock and Watson (1999), Christadoro et al. (2005), and Gosselin and Tkacz (2001) offer a similar interpretation of core inflation in motivating the inclusion of nominal, real, and foreign variables in their panels.

\section{The Identification Scheme}

The identification scheme to analyze the pass-through from import prices to CPI is similar to an event study approach used in empirical finance. These studies seek to measure the impact of an economic event (announcement, merger, macroeconomic news, etc.) on the value of firms. An important step in our identification scheme are inflation forecasts. The use of inflation forecasts instead of (actual) inflation to estimate the pass-through is motivated 
on several grounds. First, as mentioned in the introduction, the endogenous pass-through models of Taylor (2000) and Devereux and Yetman (2002) work with a forward-looking equation for inflation. Taylor (2000), in addition, emphasizes that the degree of pass-through is important for inflation forecasting. Thus, the intention is not to compare the weights between the import share with the common factor estimates, but to capture the second round effects stemming from import prices. Second, we want to understand in a real-time setting, what is the marginal contribution from the latest observation in import prices on the inflation dynamics. As in a VAR setup, if the inflation forecasts respond strongly to import prices, then this is consistent with a pass-through from import prices to consumer prices. Third, it should be recognized that one weakness of data reduction procedures by Stock and Watson (2002) and Forni et al. (2000) is that the estimated common factors are not interpretable. This forces the pass-through analysis to focus on whether new information influences the forecasts rather than the traditional route of identifying coefficients from regression equations. Below, the main steps of the estimation procedure are defined using the terminology of MacKinlay (1997).

\section{Defining the Event: Import Price Releases}

The monthly release of import prices is defined to be the event with the 
$p$ th event date $\tau_{p}=(j, t)$ corresponding to day $j$ and month $t$ in calendar time and $p=\{1, \cdots, 18\} .{ }^{12}$ The structure of the daily panels allows us to examine the marginal contribution from 18 events on inflation forecasts conditional on panel $P(k)_{j, t}$ for $k=\{1, \cdots, 4\}$ at time $(j, t)$. A one-day event window is used so that only information from import price releases is captured. ${ }^{13}$

\section{The Forecasting Model and Estimation}

The forecasting model relies on data reduction techniques that can handle daily panels. ${ }^{14}$ To do this we follow the estimation procedures of Forni et

\footnotetext{
${ }^{12}$ Since we seek to replicate a real-time setting of daily sequential information flow with the focus on import price releases. Import price releases offer a natural event date whereas other variables used to calculate the pass-through, such as exchange rates, do not.

${ }^{13}$ Producer prices are released at the same time as are import prices, but this information is not included in our panel. Hence, we assume revision error (see footnote 9) and producer prices do not influence inflation forecasts. To check the latter claim, we estimated panel $P(4)$ with an additional 20 series for producers prices for the full sample and checked these forecasts against against those from $P(4)$. A test of independence could not be rejected when projecting on CPI inflation.

${ }^{14}$ Recent contributions by Evans (2005) and Giannone et al. (2005) are also concerned with real-time forecasting based on data releases. These papers focus on estimation for the current quarter ("nowcasts") instead of forecasts as we do. Our proposed procedure differs in that it works with daily panels and therefore the event window of the news component is time invariant. This allows us to distinguish between time and variable as
} 
al. (2000), Christadoro et al. (2005), and Altissimo et al. (2001). We offer a descriptive outline of the estimation procedure and refer the reader to the individual papers for specific details.

As in Forni et al. (2000), we assume that the factor structure has $N$ variables in the panel, $x_{t}=\left(x_{1, t}, x_{2, t}, \cdots, x_{N, t}\right)^{\prime}$. Further, we assume that the variables in $x_{t}$ are measured with error and that they can be decomposed into the sum of two orthogonal components: the signal $x_{i, t}^{*}$ and the measurement error $e_{i, t}$

$$
x_{i, t}=x_{i, t}^{*}+e_{i, t},
$$

where $i$ denotes the $N$ variables and $t$ denotes time in months. Next, under suitable conditions on the variance-covariance matrix of the $x^{\prime} s$ defined in Forni et al. (2000), $x_{i, t}$ is specified as a generalized dynamic factor model:

$$
x_{i, t}=\chi_{i, t}+\xi_{i, t}=b_{i 1}(L) f_{1, t}+\cdots+b_{i q}(L) f_{q, t}+\xi_{i, t},
$$

where $\xi_{i, t}$ is the idiosyncratic component and $\chi_{i, t}=x_{i, t}-\xi_{i, t}$ is the common component. ${ }^{15}$ The latter consists of $q$ dynamic common factors, $f_{t}=$ $\left(f_{1, t}, \cdots, f_{q, t}\right)^{\prime}$, and $b_{i j}(L)$ is of order $q$.

possible sources of innovations.

${ }^{15}$ Hereafter, we refer to them as 'idiosyncratic' and 'common'. Note, the latter refers to the common component, $\chi_{i t}$, and not to the common factor, $f_{t}=\left(f_{1, t}, \cdots, f_{q, t}\right)^{\prime}$. 
The estimation procedure for $\chi_{i, t+h \mid P(k)}$, the forecast of $\chi_{i, t} h$ periods ahead conditional on panel $P(k)$ for $k=1$ to 4 , follows Cristadoro et al. (2005). We begin with the estimation of the spectral density matrices of the common and the idiosyncratic using the method of dynamic principal components of Forni et al. (2000). Next, we use the variance-covariance matrices of the common and the idiosyncratic component implied by the spectrum in the first step to estimate the static factors by generalized principal components. As in Amstad and Fischer (2004), we work with two dynamic factors and twelve static factors. ${ }^{16}$ In a further step, we estimate the common component at low frequency by using the static factors. This last step involves performing a projection of the common component at low frequency on the leads and lags of the estimated static factors.

To generate the forecasts, we apply the shifting procedure for the covariance matrix by Altissimo et al. (2001). ${ }^{17}$ Altissimo et al. (2001) compute

\footnotetext{
${ }^{16}$ This has been tested in Amstad and Fischer (2004). Also many empirical studies find that two dynamic factors represent the panel's variance well. See Giannone and Lenza (2004) for savings and investment in OECD countries and Giannone et al. (2004) for the United States.

${ }^{17}$ Giannone et al. (2004) offer an alternative procedure for forecasts of the common component based on the Kalman filter.
} 
values of $\chi_{i, t}$ in (2) $h$ months ahead by individually shifting out each series in $x_{i, t}$ in a way that the most recent observation aligns $h$ months ahead. Afterwards the generalized principal component is evaluated for the realigned $x_{i, t}$; see Appendix 2 for further discussion. A further important step in our forecasting procedure is to apply the band-pass filter before projecting. Our decision to work with the low frequency component with cutoff $2 \pi / 12$ introduces a smoothed common component. ${ }^{18}$ For the forecasts, this implies that the noise component should not have a large influence on the forecasts. We therefore interpret changes to the updated forecast to be attributed to new information from the import price release and not to measurement error. ${ }^{19}$

\section{Abnormal Forecast Innovations}

We follow the terminology in the event study literature, which uses the term "abnormal returns" as its response measure to the examined event.

\footnotetext{
${ }^{18}$ Seasonality is a further motive for using the bandpass filter. Giannone et al. (2005) use de-seasonalized data, Evans (2005) does not address this issue. To avoid the end of sample problem for seasonal filtering for our forecasts, we apply the bandpass filter with $2 \pi / 12$. Amstad and Fischer (2004) have found that this strategy works well.

${ }^{19}$ Note that changes in forecasts due to estimation errors would be reflected in changing estimation parameters. As fixing parameters has little or no impact on our forecasts, estimation uncertainty should be low.
} 
This is defined as the actual ex post return of the security over the event window minus the normal return, i.e., the return that would be expected if the event did not take place. Instead of returns, we work with inflation forecasts in order to capture the dynamics of the pass-through. Thus, to identify the influence of new information from monthly releases in import prices, a measure of (abnormal) forecast innovations for event date $\tau_{p}=(j$, $t)$ is needed. This is defined as the one-day difference in the $h$-period ahead forecasts of $\chi_{i, t+h}$ around the release dates of import prices. More specifically, $\epsilon_{\pi^{s}, t+h \mid P(k)_{j, t}}$ and $\epsilon_{\pi^{f}, t+h \mid P(k)_{j, t}}$ are innovations from the forecast for CPI $\left(\pi^{s}=\right.$ $\left.\Delta p^{s}\right)$ and CPI minus administrative prices $\left(\pi^{f}=\Delta p^{f}\right)$ inflation with forecast horizon $t+h$ conditional on the daily information panel $P(k)_{j, t}$ before and after the release of import prices (for the month of $t-1$ ) on day $j$ in month $t$ :

$$
\begin{aligned}
\epsilon_{\pi^{s}, t+h \mid P(k)_{j, t}} & =\chi_{\pi^{s}, t+h \mid P(k)_{j, t}}-\chi_{\pi^{s}, t+h \mid P(k)_{j-1, t}}, \\
\epsilon_{\pi^{f}, t+h \mid P(k)_{j, t}} & =\chi_{\pi^{f}, t+h \mid P(k)_{j, t}}-\chi_{\pi^{f}, t+h \mid P(k)_{j-1, t}} .
\end{aligned}
$$

In equations (3) and (4), import prices are released with a one-month delay and $P(k)_{j-1, t}$ refers to the data panel that does not include the import price release for month $t$-1, whereas the next day's panel $P(k)_{j, t}$ does. The forecast innovations are defined as the information attributed to the monthly release 
of import prices.

Definition of a Successful Event (direction of forecast innovation)

"Successful event" is a term used in the event study literature to refer to responses, which match a directional criteria without referring to the magnitude of the change. There is no established directional criteria of a successful pass-through event from import prices to inflation forecasts. We define the event to be a success if either

$$
\begin{aligned}
& \left(\Delta p_{t-1}^{i m p}>0 \text { and } \epsilon_{\pi^{s}, t+h \mid P(k)_{j, t}}>0\right) \quad \text { or } \quad\left(\Delta p_{t-1}^{i m p}<0 \text { and } \epsilon_{\pi^{s}, t+h \mid P(k)_{j, t}}<0\right), \\
& \left(\Delta p_{t-1}^{i m p}>0 \text { and } \epsilon_{\pi^{f}, t+h \mid P(k)_{j, t}}>0\right) \quad \text { or } \quad\left(\Delta p_{t-1}^{i m p}<0 \text { and } \epsilon_{\pi^{f}, t+h \mid P(k)_{j, t}}<0\right) .
\end{aligned}
$$

This says that the direction of the change in last month's (total) import prices, $\Delta p_{t-1}^{i m p}$, and the direction of forecast innovations for $\pi^{s}$ and $\pi^{f}$ should be the same. The criteria do not establish the size of the pass-though. ${ }^{20}$ The success criterion assumes that the direction of total import prices is representative for the 15 other import price indexes. To test for direction using $\pi=\left\{\pi^{s}, \pi^{f}\right\}$, we construct two indicator functions $I_{t}^{i m p}=1$ if $\Delta p_{t-1}^{i m p}$ $>0$; else $I_{t}^{i m p}=-1$ and $I_{t}^{\pi}=1$ if $\epsilon_{\pi, t+h \mid P(k)_{j, t}}>0$; else $I_{t}^{\pi}=-1$ and then test if $I_{t}^{\pi}=I_{t}^{i m p}$ using a rank test.

\footnotetext{
${ }^{20} \mathrm{~A}$ simple point estimate is defined in the next section.
} 


\section{Import Price Releases and Inflation Forecasting}

This section offers empirical results on the real-time informational contribution from import price releases on inflation forecasts. All forecasts have a horizon of up to 24 -months, i.e., $h=\{1,2, \cdots, 24\} .{ }^{21}$ The process of smoothing the inflation forecast with the band pass filter reduces the contribution coming from random noise at the time of the import price release and at the same time biases downward our pass-through estimates.

The first part of the analysis establishes the main empirical properties of the abnormal forecast innovations. This includes the main empirical result; import prices offer valuable information for inflation forecasts. ${ }^{22}$ Next, the estimates of a time-varying pass-through are presented. This is then followed by two robustness checks. The first determines the importance of the information breadth defined by the four panels and the second seeks to determine whether price rigidity captured through administrative price setting has any bearing on our results.

\section{Properties of Abnormal Forecast Innovations}

\footnotetext{
${ }^{21}$ The choice of $\max _{h}=24$ ensures that the maximum response of the inflation forecasts to monthly import prices falls well within the defined time horizon.

${ }^{22}$ Appendix 3 provides empirical evidence that the RMSEs of the forecasting models based on panels $P(1)$ to $P(4)$ are lower than a naive and $\mathrm{AR}(3)$ model.
} 
The main properties of the forecast innovations for CPI inflation $\left(\pi^{s}\right)$ and CPI minus administrative price inflation $\left(\pi^{f}\right)$ are tabulated in Table 2 . The first six rows offer information on the forecasts innovations, $\epsilon_{\pi, t+h \mid P(k)_{j, t}}$. Figure 5 reproduces much of this information for the four panels in that the maximum response to import prices releases (denoted as $\max _{t}\left(\max _{h}\left(\left|\epsilon_{\pi^{*}, t+h \mid P j}\right|\right)\right)$ in Table 2), minimum response (denoted $\min _{t}\left(\max _{h}\left(\left|\epsilon_{\pi^{*}, t+h \mid P j}\right|\right)\right)$ in Table 2) and average response (denoted by the bar-line in Figure 5) of the forecast innovations for CPI and for CPI without administered prices are presented. Several observations are noteworthy.

First, the monthly pass-through proxied by $\epsilon_{\pi, t+h \mid P(k)_{j, t}}$ is not zero; statistical evidence is provided below in Tables 3 and 4 . Second, average peak size declines with the information breadth of the panel. The importance of the information from import price releases in the inflation forecast diminishes when large information sets are considered. This result is true for both inflation measures with CPI without administered prices reacting slightly stronger than CPI prices. A third observation concerns the large volatility of $\epsilon_{\pi, t+h \mid P(k)_{j, t}}$. The maximum amplitude for $\pi^{f}$ based on the information set $P(2)$, for example, is 0.3720 versus a minimum of 0.0103 . Both were at a 
time when CPI inflation was $0.9 \% .^{23}$

To test whether the direction of forecast innovations is compatible with the direction of the monthly change in total import prices a Wilcoxon rank test is presented in Table 2. The test under the null is that the monthly direction of $\Delta p_{t-1}^{i m p}$ and $\epsilon_{\pi, t+h \mid P(k)_{j, t}}$ are the same. The $p$-values of the rank test are presented in the row labelled Direction. The evidence finds that the direction is consistent for the information panels $P(1)$ and $P(2)$. The test clearly rejects the information set $P(4)$ for both inflation measures. For $P(3)$, the results are inconclusive. The null is rejected in the case of $\pi^{s}$ but not for $\pi^{f}$. A potential explanation is that exchange rates, which are included in $P(3)$ but not in $P(2)$, have an impact on non administered prices but no influence on CPI prices. This means that $P(3)$ entails overlapping information with respect to import prices.

Tables 3 and 4 provide evidence on whether the populations generating the two forecasts are different from zero. Results from a Wilcoxon rank test (see Diebold and Mariano (1995) statistic for $S_{3}$ ) are presented for the stacked innovations and for the individual months. A $p$-value less than 0.05 is to be

\footnotetext{
${ }^{23}$ Estimation uncertainty can be considered as a minor reason for additional volatility in the pass-through estimates, see also footnote 17.
} 
interpreted such that the distributions of the forecast innovations degenerate on zero. The evidence finds that the null hypothesis is rejected for almost all the innovations from the individual months and the stacked forecast innovations, except for $\pi^{f}$ with panel $P(4) .{ }^{24}$ We interpret the evidence as showing that inflation forecasts respond to information from monthly import price releases.

\section{Pass-Through Estimates}

Figure 6 presents a scatter plot of the monthly pass-through from import prices to inflation forecasts versus the time duration in the forecast innovations' peak, i.e., $f=g\left(\max _{h}\left(\left|\epsilon_{\pi, t+h \mid P(k)_{j, t}}\right|\right)\right)$. More precisely, the passthrough measure is defined as $\max _{h}\left(\left|\epsilon_{\pi, t+h \mid P(k)_{j, t}}\right|\right) * I_{t}^{\pi} / \Delta p_{t-1}^{i m p}$, where the indicator variable, $I_{t}^{\pi}$, preserves the sign of the forecast innovation (i.e., $I_{t}^{\pi}$ $=+1$ if $\epsilon_{\pi, t+h \mid P j}>0$; otherwise $I_{t}^{\pi}=-1$ ). The displayed point estimates for the monthly pass-through are bounded between -1 and +1 and include

\footnotetext{
${ }^{24}$ Diebold and Mariano (1995) show in their Tables 5 and 6 that the Wilcoxon rank test holds up well even in in the presence of serial and contemporaneous correlation and smaller samples than ours. Our forecast innovations have 24 observations, are not highly serially correlated, and are symmetric in distribution. An alternative test, the sign test with slightly lower power, yielded similar results for the innovation's median being different from zero.
} 
estimates for CPI and for CPI minus administrative prices conditional on our four panels. ${ }^{25}$ The monthly pass-through estimates fluctuate strongly and are skewed to the left, whereas the lag length of the maximum response fluctuates less and are symmetrically distributed ${ }^{26}$ The former result underscores the view that pass-through estimates are not uniform. This result has been shown in Campa and Goldberg (2002), Choudhri and Hakura (2001), Devereux and Yetman (2002), and Goldberg and Knetter (1997). They find a high variance in the pass-through estimates across countries and industry, but no study has noted this for single country estimates for a low inflation regime.

The median size of the pass-through from import prices to CPI inflation is 0.13 (average is 0.11 ) and the median lag length is 9 months (average is 8.1 months). ${ }^{27}$ If the Goldberg and Knetter (1997) proxy of 0.5 is acknowledged

\footnotetext{
${ }^{25}$ Roughly a quarter of the estimates fall outside the +1 to -1 range. This stems from the fact that the change in total import prices is close to zero.

${ }^{26}$ The level of skewness for the point estimates is significant at the $0.05 \%$ critical level with a statistic of -1.22 . The skewness statistic for the lag length is 0.26 and is not significant.

${ }^{27}$ The median for the pass-through estimates conditional on panels $P(1)$ and $P(2)$ bounded between +1 and -1 is 0.32 and the median estimates conditional on $P(3)$ and $P(4)$ is 0.11 .
} 
as an acceptable pass-through estimate from exchange rates to import prices, then the median (time-varying) estimate for all panels of 0.13 is in line with the time series estimates for Switzerland found in Choudri and Hakara (2001), Gagnon and Ihrig (2004), and Stulz (2005). Their point estimate for the exchange rate pass-through to Swiss consumer prices for a sample period that includes the $1990 \mathrm{~s}$ is $0.07 .^{28}$

To understand further whether Taylor's (2000) claim that the pass-through is linked to inflation also holds in the short run for a low inflation regime, causality tests between the two variables were performed. Table 5 provides rudimentary evidence that annualized inflation, $\pi_{t}$ does not Granger cause the 18 pass-through estimates from import prices to inflation. The tests, based on two lags, find that the null hypothesis of non causality is not rejected for each of the four panels. This result underpins the view that the time-varying behavior of our pass-through estimates are not explained by short-run movements in past inflation. The observation of a low first-order correlation for inflation (i.e., less than $10 \%$ for both inflation measures) is one explanation for the causality results and does not allow us to refute Taylor's

\footnotetext{
${ }^{28}$ Devereux and Yetman (2002) estimate the exchange rate pass-through for Switzerland
} to be 0.02 . 
(2000) claim that the pass-through only matters when inflation is persistent for a high inflation regime. ${ }^{29}$

\section{Price Rigidity}

To determine whether price rigidity matters for our pass-through measure, two tests are conducted. The first compares whether the forecast innovations for CPI inflation, $\epsilon_{\pi^{s}, t+h \mid P(k)_{j, t}}$, and CPI non administrative inflation, $\epsilon_{\pi^{f}, t+h \mid P(k)_{j, t}}$, are equal. The second test considers the importance of the information sets in generating the forecast innovations. The tests seek to determine if $P(1)$, the panel without administered prices, behaves qualitatively different from broader panels, i.e., $P(2), P(3), P(4)$.

Table 6 provides $p$-values for the test under the null that the forecast innovations for $\pi^{s}$ and $\pi^{f}$ are equal: $\epsilon_{\pi^{s}, t+h \mid P(k)_{j, t}}=\epsilon_{\pi^{f}, t+h \mid P(k)_{j, t}}$. Four tests conditional on panels $\{P(1), \cdots, P(4)\}$ are performed. The evidence finds that the information from rigid prices through administrative price setting have no influence on the forecast innovations. The Wilcoxon-rank tests are unable to reject the null except for a handful of months. This result applies for all information sets $\{P(1), \cdots, P(4)\}$.

\footnotetext{
${ }^{29}$ In a similar manner, Campa and Goldberg (2002) argue that Taylor's (2000) argument carries weight only when inflation is high.
} 
Next, the importance of the information sets in generating the forecast innovations is tested. To do this, rank tests with the null that $\epsilon_{\pi^{s}, t+h \mid P(k)}=$ $\epsilon_{\pi^{s}, t+h \mid P(l)}$ and $\epsilon_{\pi^{f}, t+h \mid P(k)}=\epsilon_{\pi^{f}, t+h \mid P(l)}$ for $k \neq l$ are used. The $p$-values of the rank tests are given in Table 7 for $\pi^{f}$ and Table 8 for $\pi^{s}$. The results find that the null $\epsilon_{\pi^{s}, t+h \mid P 1}=\epsilon_{\pi^{s}, t+h \mid P 2}$ and $\epsilon_{\pi^{f}, t+h \mid P 1}=\epsilon_{\pi^{f}, t+h \mid P 2}$ cannot be rejected, whereas the innovations generated from other panels are statistically different. The $p$-values are well above the critical level of $0.05 \%$ for $P(1)$ and $P(2)$. The null hypothesis of equality is only rejected for five isolated months. This result means that information from administrative prices does not improve the inflation forecasts: a result consistent with the evidence from Table 6.

\section{Concluding Remarks}

This paper presents a new empirical strategy to identify the pass-through from import prices to CPI inflation in real time. The time-dependent procedure has parallels to the event study framework used in empirical finance. An important step is the forecasting procedure based on daily panels. It relies on the data reduction techniques by Forni et al. (2000) and builds on earlier work by Amstad and Fischer $(2004,2005)$. The forecasting exercise 
centered around import price releases offers three new empirical findings.

First, the monthly pass-through is time varying even when controlling for a low inflation regime. Differences in the maximum and minimum response of the inflation forecasts to the data releases are observed. Although the point estimates reveal a relatively small (median) pass-through from import prices to consumer prices, the pass-through is found to be statistically different from zero. This result is underpinned by the directional evidence for prices. When new information in total import prices reflects a rise (fall) in foreign prices, this leads to an increase (decrease) in the revised inflation forecast.

Second, monthly releases in import prices are an important information source for inflation forecasts. The result is dependent on the information breadth of the daily panel; a feature that has not been examined in previous pass-through studies. The size and significance of the forecast innovation with respect to new information stemming from the monthly release of import prices is largest for the narrowest panel and smallest for the largest panel. In the latter case, estimates for a compatible measure of core inflation based on a data rich environment do not respond to import price releases. This result suggests that the additional variables in the larger panels are already capturing the information from import price releases. 
Third, there is no difference in the innovations stemming from the CPI inflation forecasts before and after the release in import prices and in those innovations using the non administered CPI prices. If administered prices are recognized as a form of nominal rigidity, the empirical results do not support theoretical models based on Calvo (1983) pricing decisions.

The time-varying pass-through estimates need to be qualified, however. First, the estimates are for a limited sample and could also be country specific. Hence, more empirical work is needed for other countries. Second, the measure of non administered prices may be too narrow to make valid claims of price rigidity for non tradable goods. Burstein et al. (2005) argue that the traded goods component of the CPI is economically narrower than measured by statistical agencies. Despite these shortcomings, the identification of passthrough measures in real time offers new insights that cannot be analyzed with standard regression techniques. 


\section{References}

Altissimo, F., A. Bassanetti, R. Cristadoro, M. Forni, M. Hallin, M. Lippi, L. Reichlin, and G. Veronese, 2001 "A Real Time Coincident Indicator of the Euro Area Business Cycle," CEPR Discussion Paper \#3108.

Amstad, M. and A. M. Fischer, 2005, "Shock Identification of Macroeconomic Forecasts based on Daily Panels," Federal Reserve Bank of New York, Staff Reports \#206.

Amstad, M. and A. M. Fischer, 2004, "Sequential Information Flow and Real-Time Diagnosis of Swiss Inflation: Intra-monthly DCF Estimates for a Low Inflation Environment," CEPR Discussion Paper \#4627.

Bailliu, J. and E. Fujii, 2004, "Exchange Rate Pass-Through and the Inflation Environment in Industrialized Countries: An Empirical Investigation," Bank of Canada Working Paper \#2004-21.

Betts, C. and M. B. Devereux, 1996, "The Exchange Rate in a Model of Pricing to Market," European Economic Review Vol. 40(3-5), pp. 10071021.

Bils, M.and P. J. Klenow, 2004, "Some Evidence on the Importance of Sticky Prices," Journal of Political Economy Vol. 112, pp. 947-985.

BIS, 2005, "75 Annual Report," Bank for International Settlements, Basel, Switzerland.

Boivin, J. and S. Ng 2005, "Are More Data Always Better for Factor Analysis?," Journal of Econometrics forthcoming.

Burstein, A, M. Eichenbaum, and S. Rebelo, 2005, "Large Devaluations and the Real Exchange Rate," Journal of Political Economy forthcoming.

Calvo, G., 1983, "Staggered Prices in a Utility-Maximizing Framework," Journal of Monetary Economics Vol. 12, pp. 383-398.

Campa, J. M. and L. S. Goldberg, 2002, "Exchange Rate Pass-Through into Import Prices: A Macro or Micro Phenomenon?," NBER Working Paper \#8934.

Chari, V. V., P. J. Kehoe, and E. R. McGratten, 1998, "Can Sticky Price 
Models Generate Volatile an Persistent Real Exchange Rates?," Federal Reserve Bank of Minneapolis Research Department, Staff Report \#233.

Choudri, E. U. and D. S. Hakura, 2001, "Exchange Rate Pass-Through to Domestic Prices: Does the Inflationary Environment Matter?," IMF Working Paper \#WP/01/194.

Cristadoro, R., M. Forni, L. Reichlin, and G. Veronese, 2005, "A Core Inflation Index for the Euro Area," Journal of Money, Credit, and Banking Vol. 37(3), pp. 539-560.

Cunningham, A. and A. G. Haldane, 2002, "The Monetary Transmission Mechanism in the United Kingdom: Pass-Through and Policy Rules," Central Bank of Chile, Working Paper No. 83.

Devereux, M. B. and J. Yetman, 2002, "Price-Setting and Exchange Rate Pass-Through: Theory and Evidence," Bank of Canada Conference, 347371.

Diebold, F. X. and R. S. Mariano, 1995, "Comparing Predictive Accuracy," Journal of Business and Economic Statistics Vol. 13(3), pp. 253-263.

Engel, C., 2002, "The Responsiveness of Consumer Prices to Exchange Rates: A Synthesis of some New Open-Economy Macro Models," The Manchester School Vol. 70 (Supplement), pp. 127-176.

Evans, M. D. D. 2005, "Where Are We Now? Real-Time Estimates of the Macro Economy," International Journal of Central Banking Vol. 1(2), pp. $127-176$.

Fischer, A. M., 2002, "Fluctuations in the Swiss Franc: What Has Changed Since the Euro's Introduction?," Journal of Public Policy 22(2), pp. 143159 .

Forni, M., M. Hallin, M. Lippi, and L. Reichlin, 2000, "The Generalized Dynamic-Factor Model: Identification and Estimation," Review of Economics and Statistics Vol. 82, pp. 540-554.

Forni, M., M. Hallin, M. Lippi, and L. Reichlin, 2001, "Do Financial Variables Help Inflation and Real Activity in the Euro Area," Journal of Monetary Economics Vol. 50, pp. 1243-1255. 
Gagnon, J. E. and J. Ihrig, 2004, "Monetary Policy and Exchange Rate Pass-Through," Board of Governors of the Federal Reserve System, International Finance Discussion Papers \#704 (revised version).

Giannone, D., L. Reichlin, and D. Small, 2005, "Nowcasting GDP an Inflation: The Real Time Informational Content of Macroeconomic Data Releases," mimeo.

Giannone, D., L. Reichlin, and L. Sala, 2004, "Monetary Policy in Real Time," NBER Macroeconomics Annual, Mark Gertler and Ken Rogoff Editors, MIT Press (forthcoming).

Giannone, D. and M. Lenza, 2004, "The Feldstein-Horioka Fact," CEPR Discussion Paper \#4610.

Goldberg, P. K. and M. N. Knetter, 1997, "Goods Prices and Exchange Rates: What Have We Learned?," Journal of Economic Literature Vol. 35(3), pp. 1243-1272.

Goodhart, C. and B. Hofmann, 2000, "Do Asset Prices Help to Predict Consumer Price Inflation?," Manchester School Supplement Vol. 68, pp. 122140.

Gosselin, M. A. and G. Tkacz, 2001, "Evaluating Factor Models: An Application to Forecasting Inflation in Canada," Bank of Canada Working Paper 2001-18.

Khotari, S. P. and J. B. Warner, 2005, "Econometrics of Event Studies," in Espen Eckbo, B. (Ed.), Handbook of Corporate Finance: Empirical Corporate Finance (Handbooks in Finance Series, Elsevier/North Holland), Chapter 1, forthcoming.

Kollmann, R. 1997, "The Exchange Rate in a Dynamic Optimizing Current Account Model with Nominal Rigidities: A Quantitative Investigation," International Monetary Fund, IMF WP97/7.

Lane, P. R., 2001, "The New Open Economy Macroeconomics: A Survey," Journal of International Economics Vol. 54, pp. 235-266.

Levin, A. T. and J. M. Piger, 2002, "Is Inflation Persistence Intrinsic In Industrial Countries?," Federal Reserve Bank of St. Louis, Working Paper, \#2002-023E. 
MacKinlay, A. C., 1997, "Event Studies for Economics and Finance," Journal of Economic Literature Vol. 35, pp. 13-39.

McCarthy J., 2000, "Pass-Through of Exchange Rates and Import Prices to Domestic Inflation in Some Industrialized Economies," Research Department, Federal Reserve Bank of New York, manuscript.

Reichlin, L., 2003, "Factor Models in Large Cross Sections of Time Series," in Advances in Economics and Econometrics: Theory and Applications, Eight World Congress, Volume III, edited by Mathias Dewatripont, Lars Peter Hansen, and Stephen J. Turnovsky, Cambridge University Press.

Stock, J. H. and M. W. Watson, 2002, "Macroeconomic Forecasting Using Diffusion Indexes," Journal of Business and Economic Statistics Vol. 20, pp. 147-61.

Stulz, J., 2005, "Pass-Through of the Exchange Rate and Import Prices into Domestic Prices in Switzerland," mimeo.

Taylor, J. B., 2000, "Low Inflation, Pass-Through, and the Pricing Power of Firms," European Economic Review Vol. 44, pp. 1389-1408.

Taylor, J. B., 1980, "Aggregate Dynamics and Staggard Contracts," Journal of Political Economy Vol. 88, pp. 1-23. 


\section{Appendix 1: Data Transformations}

The decisions to transform the variables in the panels follow those taken in Amstad and Fischer (2005). First, no seasonal filtering is conducted because of its reliance on future information; this is not consistent with real-time forecasting. Amstad and Fischer (2004) demonstrate that seasonal adjustment can be treated through band-pass filtering. This overcomes the end-of-sample problem and the absence of seasonal revision allows us to interpret better the daily innovations in $\epsilon_{i, t+h \mid P(k)_{j, t}}$. Second, the daily panels are updated so that new information from the monthly releases are incorporated and new monthly averages are generated with the daily financial variables. The averaging of the daily information (i.e., opposed to using the latest daily observation as a proxy for the monthly observation) allows us to generate improved forecasts for our price variables based on real-time information without contaminating $\epsilon_{i, t+h \mid P(k)_{j, t}}$. Third, logarithms were taken for nonnegative series that were not in rates or in percentage units to account for possible heteroskedasticity. Fourth, the series were differenced if necessary to account for stochastic trends. Fifth, the series were taken in deviation from the mean and divided by their standard deviation to remove scalar effects. 


\section{Appendix 2: End of Sample Procedure}

To consider the most recent information defined in terms of daily panels, we use a data set which is unbalanced at sample end. Therefore some series end in $\mathrm{T}$, others in $\mathrm{T}+1, \ldots, \mathrm{T}+w$. To forecast with such an unbalanced panel, we use the method of Altissimo et al. (2001) and Christadoro et al. (2005) by reordering the variables $x_{i, t}$ in a way that

$$
x_{i, t}^{*}=\left(x_{i, t}^{1} x_{i, t}^{2} \ldots x_{i, t}^{w}\right)
$$

where $x_{i, t}^{j}, j=1, \ldots, w$ groups are variables with the same last available observation $T+j-1$. The covariance matrix is then partitioned as follows

$$
\widehat{\Gamma}^{*}(k)=\left(\begin{array}{cccc}
\widehat{\Gamma}^{11}(k) & \widehat{\Gamma}^{12}(k) & \cdot & \widehat{\Gamma}^{1 w}(k) \\
\widehat{\Gamma}^{21}(k) & \widehat{\Gamma}^{22}(k) & \cdot & \widehat{\Gamma}^{2 w}(k) \\
\cdot & \cdot & \cdot & \cdot \\
\widehat{\Gamma}^{w 1}(k) & \widehat{\Gamma}^{w 2}(k) & \cdot & \widehat{\Gamma}^{w w}(k)
\end{array}\right)
$$

and accordingly for the covariance matrix of the common $\widehat{\Gamma}_{\chi}^{*}(k)$ and the covariance matrix of the idiosyncratic $\widehat{\Gamma}_{\xi}^{*}(k)$ as well. ${ }^{30}$ After shifting the variables in such a way to retain, for each one of them, only the most updated observation, the generalized principal components is computed for the realigned vector $\widehat{\Gamma}_{\xi}^{*}(k)$ to get the forecasts. The final step is to restore the original alignment. The procedure is described in greater detail in Christadoro et al. (2005).

\footnotetext{
${ }^{30} \widehat{\Gamma}_{\xi}^{*}(k)$ is diagonal and therefore the realigned $\widehat{\Gamma}_{\xi}^{*}(k)$ equals the original $\widehat{\Gamma}_{\xi}(k)$.
} 


\section{Appendix 3: Forecast Evaluation}

Table A3 presents RMSEs for CPI forecasts from three different models: naive, $\mathrm{AR}(3)$, and our preferred dynamic common factor (DCF) model based on panels $P(1)$ to $P(4)$, denoted as $D C F(\mathrm{P} 1)$ to $D C F(\mathrm{P} 4)$ in Table A3. The naive and $\mathrm{AR}(3)$ models are simple benchmarks that are frequently able to outperform more sophisticated models over longer forecast periods. To determine how the information breath influences the DCF forecasts, the results for $D C F(\mathrm{P} 1)$ to $D C F(\mathrm{P} 4)$ are also considered. The naive forecasts keep the last observed CPI inflation rate constant over the forecast horizon, whereas the $\operatorname{AR}(3)$ forecasts are with-in-sample forecasts. The later forecasts work with forward information and thus assume a stronger information structure than the DCF forecasts, which are out-of-sample forecasts.

The rolling forecast period is from 2001:1 to 2003:10 and the estimates are based on information that begins in 1993:5. RMSEs, based on 34 observations, are calculated for four (cumulative) forecast horizons: 1 to 6 months ahead, 1 to 12 months ahead, 1 to 18 months ahead, and 1 to 24 months ahead. The results find that the DCF forecasts improve slightly as the size of the panel increases. Hence, our panels do not suffer from the Boivin and $\mathrm{Ng}$ (2005) critic that more variables do not necessarily improve the forecast. Over all horizons, the DCF forecasts outperform the $\mathrm{AR}(3)$ and naive forecasts.

Table A3: RMSEs for DCF Model versus Naive and AR Forecasts

\begin{tabular}{ccccccc}
\hline forecast horizon & Naive & $A R(3)$ & $D C F(\mathrm{P} 1)$ & $D C F(\mathrm{P} 2)$ & $D C F(\mathrm{P} 3)$ & $D C F(\mathrm{P} 4)$ \\
\hline 1 to 6 months & 0.060008 & 0.054547 & 0.047659 & 0.042331 & 0.041040 & 0.032626 \\
1 to 12 months & 0.143551 & 0.097464 & 0.093667 & 0.085012 & 0.080808 & 0.064101 \\
1 to 18 months & 0.241008 & 0.144003 & 0.142446 & 0.133600 & 0.128032 & 0.110418 \\
1 to 24 months & 0.313176 & 0.187717 & 0.186807 & 0.178166 & 0.172916 & 0.155364 \\
\hline
\end{tabular}


Table 1: Data Series, Periodicity and Transformation

\section{Data Panels are defined as follows}

$P(1)$ (domestic prices- non adm.) rows 1 to 177

$P(2)$ (domestic CPI prices)

$P(3)$ (prices plus financial var)

$P(4)$ (prices plus real variables)

rows 1 to 193

rows 1 to 269

rows 1 to 449

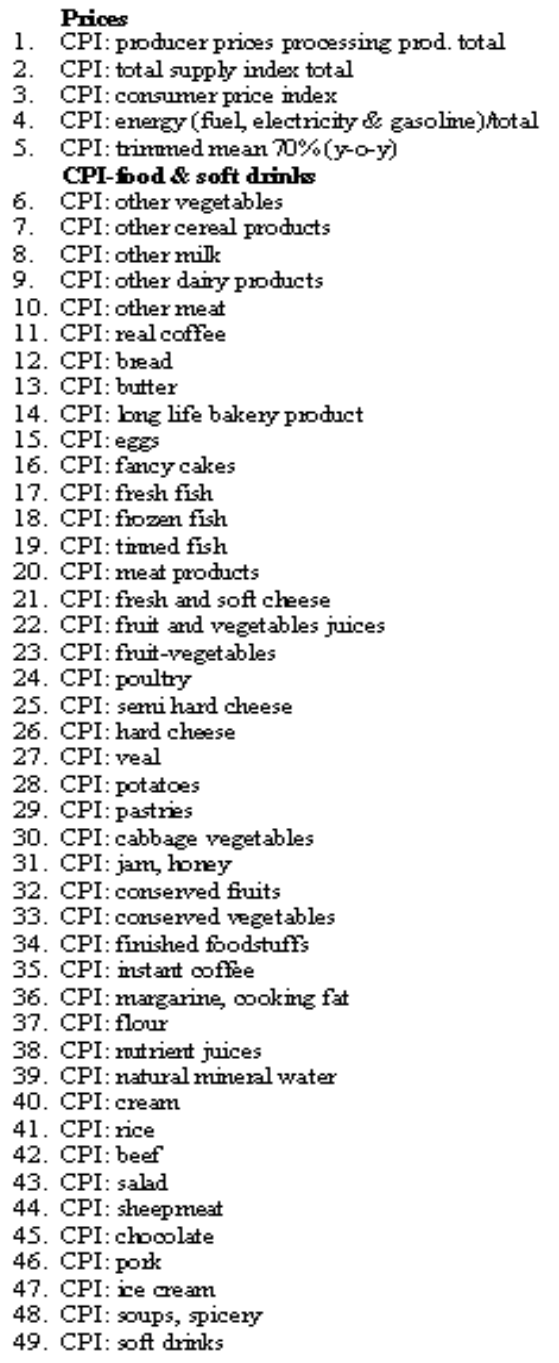

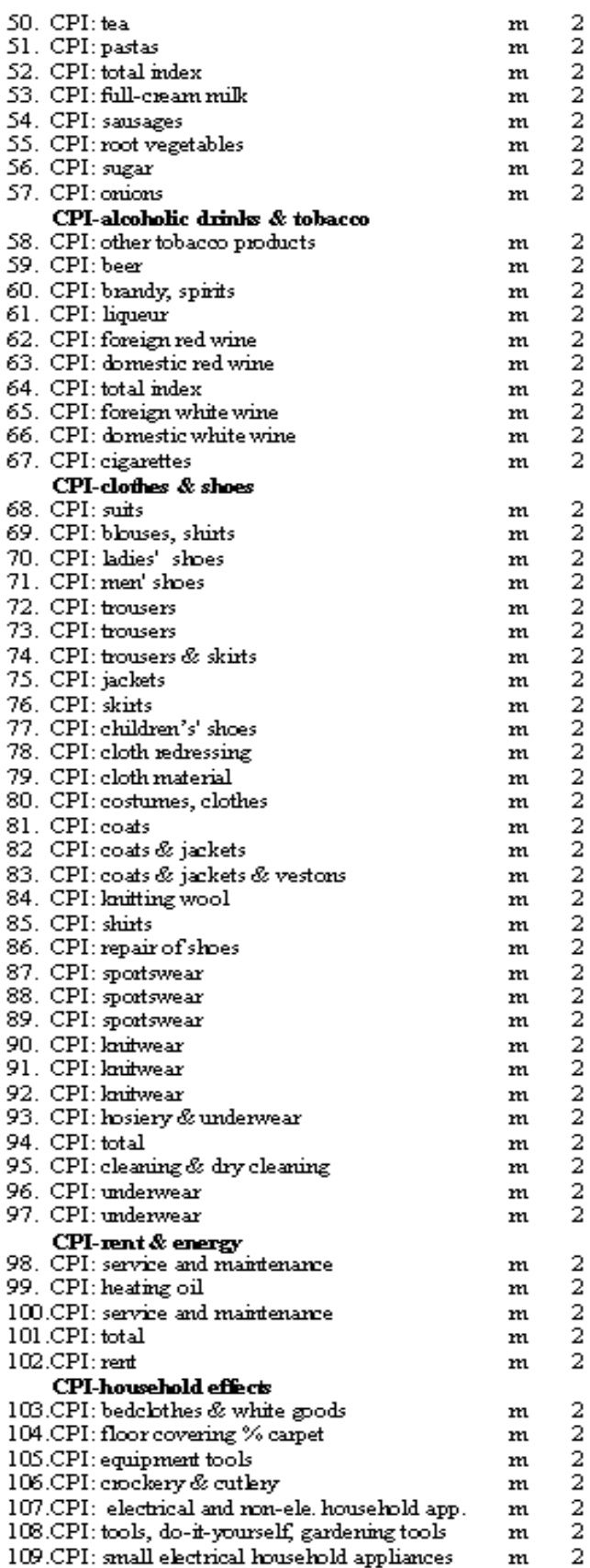


Table 1: (continued)

110.CPI: kitchen \& garden

111.CPI: kitchen \& cooking utensils

112.CPI: do-it-yourself \& gardening tools

113.CPI: cleaming tool

114.CPI: sleeping utilities

115.CPI: other expendable goods

116.CPI: total

117.CPI: curtain

118.CPI: cleaming agents

119.CPI: habitation

CPI-traffic, public transpont

120.CPI: bicycles

121.CPI: motorbikes

122.CPI: new cars

123.CPI: tires

124.CPI: services \& repairs

125.CPI: service utilities

125.CPI: total

127.CPI: fuel

CPI-news transport, communications

$128 . C P I$ : news tramsport, commmications

129 .CPI: $\mathrm{HiF}$

130.CPI: recording utilities

131.CPI: books \& pamphlet

132.CPI: office equipment

133.CPI: TV \& video

134.CPI: photo, cinema \& optical instruments

135.CPI: pets

136.CPI: bisure courses

137.CPI: package tour

138.CPI: plants

130.CPI: repair \& intallation

140.CPI: writing \& drawing materials

141.CPI: toys \& hobby tool

142.CPI: total

CPI-restaurants $\&$ hotels

143.CPI: bee

144.CPI: hotel business

145.CPI: coffee $\&$ tea

146. CPI: meals in restaurants and cafés

147. CPI: mineral water \& soft drink

148.CPI: other hotel business

149.CPI: spirits \& alooholic drinks

1 SO.CPI: total

151 CPI: xine

CPI-other poducts $\&$ service

152.CPI: haidresser

electrral equipment for personal hyziene $m$

1S4 CPI: har care products

155.CPI: skin care products \& cosmetics $\mathrm{m}$

156.CPI: nor-electrical equip. for personal hygiene $\mathrm{m}$

157.CPI: stationery for personal hygiene $\mathrm{m}$

158.CPI: first-aid

159.CPI: soap \& bath additions

160.CPI: total

161.CPI: dertal car

Import prices

162.IP: azricultural Products

163.IP: food

164.IP: textile and Cloths

165.IP: wood Products

166.IP: paper product

167.IP: mimerals and oil products

168.IP: rubber and syothetics
169.IP: glass, stone, other minerals

170.IP: metal Products

171.IP: machines

172.IP: office and IT products

173.IP: automobiles

174.IP: fuminure

175.IP : semi-firished product

176.IP: proossing production total

177.IP: total inmorts

$P(1)$

CPI-Adminis tered Prices

178.CPI: mourtain raikway \& ski lift

179.CPI: train

180.CPI: public tramsport (regiomaI)

181.CPI: education, total

183 CPI: medical care

184.CPI: drugs

185.CPI: hospital care

186.CPI: (medicine) total

187.CPI: dental treatment

188.CPI: cinema

189.CPI: radio \& TV ooncession

190.CPI: spont \& leisure activity

191.CPI: theatre \& ooncert

192.CPI: (news and tramsport) other services

193.CPI: sporting event

$P(2)$

\section{Interest rates}

195 savines deposits by cantonalbanks

196. medium tem bonds by cantonal banks

197. medium tem bonds by big banks

198.transaction acoourts, weighted interest rates

199 .fixed-term deposits by big banks, 3 months

200 .govemment bonds: 2 years

201 .govemunent bonds: 3 years

202 .govemment bonds: 4 years

203 .govemunert bonds: 5 years

204. govemunent bonds: 7 years

205 govemment bonds: 10 years

206.govemment bonds: 20 years

207.CHF-Libor:: 1 morth

208.CHF-Libor:: 3 morths

200 CHF-Libor: 6 morth

210.CHF-Libor:: 12 months

211.0-ooupon: 1 year

212.0-ooupon: 3 years

213.0-ooupon: 6 years

214.0-ooupon: 9 years

215.0-ooupon: 15 years

216.0-ooupon: 20 years

Exchange rates

217.Swiss franc/ US-dollax

218.Swiss franc / yen

219. Swiss franc i eur

$\begin{array}{ll}\mathrm{m} & 2 \\ \mathrm{~m} & 2 \\ \mathrm{~m} & 2 \\ \mathrm{~m} & 2 \\ \mathrm{~m} & 2 \\ \mathrm{~m} & 2 \\ \mathrm{~m} & 2 \\ \mathrm{~m} & 2 \\ \mathrm{~m} & 2\end{array}$

$\begin{array}{ll}\mathrm{m} & 2 \\ \mathrm{~m} & 2 \\ \mathrm{~m} & 2 \\ \mathrm{~m} & 2 \\ \mathrm{~m} & 2 \\ \mathrm{~m} & 2 \\ \mathrm{~m} & 2 \\ \mathrm{~m} & 2 \\ \mathrm{~m} & 2 \\ \mathrm{~m} & 2 \\ \mathrm{~m} & 2 \\ \mathrm{~m} & 2 \\ \mathrm{~m} & 2 \\ \mathrm{~m} & 2 \\ \mathrm{~m} & 2 \\ \mathrm{~m} & 2\end{array}$

$\begin{array}{ll}\mathrm{m} & 1 \\ \mathrm{~m} & 1 \\ \mathrm{~m} & \mathrm{l} \\ \mathrm{m} & 1 \\ \mathrm{~m} & 1 \\ \mathrm{~m} & 1 \\ \mathrm{~d} & 1 \\ \mathrm{~d} & 1 \\ \mathrm{~d} & 1 \\ \mathrm{~d} & 1 \\ \mathrm{~d} & 1 \\ \mathrm{~m} & 1 \\ \mathrm{~d} & 1 \\ \mathrm{~d} & 1 \\ \mathrm{~d} & 1 \\ \mathrm{~d} & 1 \\ \mathrm{~d} & 1 \\ \mathrm{~m} & 1 \\ \mathrm{~m} & 1 \\ \mathrm{~m} & 1 \\ \mathrm{~m} & 1 \\ \mathrm{~m} & 1 \\ \mathrm{~m} & 1 \\ \mathrm{~m} & 2 \\ \mathrm{~m} & 2 \\ \mathrm{~m} & 2\end{array}$ 
Table 1: (continued)

220 .trade weighted nom. ex. rates, 24 trade partner m 221 .trade weight. real CPI based ex. rates., 24 trade $\mathrm{m}$ 222.trade weight. nom Ex. rates, 16 European trade $m$ 223 .trade weight. realex. rates., 16 Europeantrade $\mathrm{m}$ Financial

224.banks, building credil

225 .montgage credits

225.other credits

227 total credit

228. all shares

220.SPI (with reirvestmerts)

230 SPI: registered shares

231 .SPI: bearer share

232.SPI: industry

233.SPI: service

234.SPI: banks

235.SMI (without reinvestments)

236.oil Brent

237.raw material index HWWA

238 .gold $/ \mathrm{kg}$

Money

230 .currency in circulation

240 .sight deposit

241 transaction acoourts

242.money supply M 1

243 savings deposits

244. money supply $\mathrm{M} 2$

245.time deposits

246.money supply M3

247. monetary base

Foreign prices

248.USA: consumer prices

249.USA: producer prices

250.Japan: consumer prices

25l Japan: inqort price

2S2.Euro Area: consumer prices, EU hamonized

253. Euro Area: producer prices

254.GB: consumer prices

255.GB: consumer prices, hamonized CPI

256. Franoe: oonsumer prices, EU hamonized

257.Germary: import prioes

Foreign interest rates

258.USA: govermment bonds, long tem

259.USA: government bonds, short tem

260.Japan: govermment bonds

261.GB: govermment bonds, bng tem

262.GB: govemment bonds, short tem

263. Frano: govemument bonds, bre term

264.Gemary: govemunent bonds, bng term

265.Italy: pvernment bonds, long tem

266.USA: Libor, 3 month

267. Japan: Libor, 3 month

268.GB: Libor, 3 morth

269. Euro Area: Libor, 3 morth

\section{Extemal trad}

270.raw materials \& semi finished products: ex wol. $\mathrm{m}$ 271 raw mat. \& semi finished products: ex. wol. m 272 .raw materials \& semi firished products: ex. Pr. m 273.raw materials \& semi firished products: irm $\mathrm{v} . \mathrm{m}$ 274.raw mat. \& semi firished products: imp. vol m 275. raw materials \& semi finished products: inr. p. m 276.energy: export woume

277.energy: export woume index

278.energy: export price index

279 .energy: intort volume

200. energy: inwort volume index

281 .energ: inqort prioe indes

282 .crude oil: export volume

283 .crude oil: export volume index

284.crude oil: export price index

285 motor fiuel / gasoline: import wohme

286. motor fuel / gasoline: import volume index

287. motor fuel $/$ gasoline: import price index

288. motor fuel (oil base): expont vohume

289 .motor fuel (oil base): export volume index

290 . motor fuel (oil base): export price index

291 .m. f. (bas. on nat. gas \& hydro.): inqort vol

292 .m. f. (bas. on nat. gas \& hydro.): inport vol

293.m. f. (bas. on nat. gas \& hydro.): inport prioe

294. fuel export price index:

295.fuel (oilbase): import wohme

296.fuel (oilbase): import price index

297 .fuel (based on hard ooal): export vohum

298 fuel (based on han 00 al): expont robume inde

299 . fuel (based on hard ool): export price index

300 .capital goods: import vohme

301 .capital goods: inqort vohume index

302 capital goods: inmort prioe index

303.capital aoods: export volume

304.capital goods: export rohme index

305.capital poods: export price index

306 . machines \& intruments: inmort vohmme

307 machines \& motruments: 1 mont rolome index

308. machines \& intruments: export wolume $\mathrm{m}$

300 .machines \& intruments: export nobume index m

310 utility vehicles: import rohme

311 utility vehicles: export wohme

312.contruction items: irqort wohme

313.constuction items: export volume

314.consumer goods: inqout rohme

315.consumer goods: inqort rohume index

316.consumer zoods: inmort price index

317.consumer goods: export vohume

318.consumer goods: export vohume indes

319 .consumer goods: export price index

320. consumer goods: food \& huxum food ex. m

321 consumer goods: food \& huxury food exp. vol. m

322.convumer goods: food \& huxury food, exp. Pr. m

323.consumer goods: food \& huxury food, in $\Psi$. vol m

324.consumer goods: food \& huxury food, ins. vol m

325. consumer goods: food \& huxur food inm pr. m

325.other nonturable consumer goods: exp. vol. m

327.other nomdurable consumer goods: exp. vol. m

328 .other nondurable consumer goods: exp. price m

329 .other nondurable consumer goods: import vol.e m

330 .other nondurable consumer goods: import vol. m

331 other nondurable consumer goods: import pr. m

332 .other nondurable comumer goods: export vol. m

333.durable consumer goods: export rohme index m

334.durable consumer coods: export price index m

335 durable consumer goods: import phume m

336.durable consumer goods: import wohme index m 
Table 1: (continued)

337.durable consumer goods: import price index 338.precious metals \& stones: export vohume 339.precious metals \& stones: inquor volume 340.art objects \& antiques: expont vohme

341 art objects $\&$ antiques: inqort rohume 342.total (without precious metals): expont vohume m 343.total (without precious metals): expont volume m 344.total (without precious metals): export price 345.total (without precious metals): inqout volume $\mathrm{m}$ 346.total (without precious metals): inqout rohme m 347.total (without precious metals): inqout price m 348. total (with precious metals): export vohume

349 total (with precious metals): total export vahue m

350 .total exports vahue FOB

351 .total (with precious metals): total irqort wol. m

352 .total (with precious metals): total intort vahe m Survey: real trade

353.KOF-business barometer

354. tumover $(y-0-y)$ : unchanged

355 .stock ( $y-0-y)$ : unchanged

356.stock ratimg: unchanzed

357.expected purchases: unchanged

358.expected tumover: unchanged

359 .business sentiment: balanoe

360 .expected tumover: balance

361 .expected purchases: balance

362.stock: balance

363.stock (y-o-y): balance

364.tumover $(y-0-y)$ : balance

Survey: industry

365. new orders (m-o-m): unchanged

366. new orders $(y-0-y)$ : unchanged

368.backlog of orders: unchanged

369.production (m-o-m): unchanged

370.production $(y-0-y)$ : unchanged

371 stock of inter. products ( $m-0-m)$ unchanged $\mathrm{m}$

373 stock of finished

374 stock of firished products: unchanged $\mathrm{m}$

375.expected new orders: unchanged

377. plar

378 new onders (mo-m): balme

379.new orders $(y-0-y)$ : balance

380 .backlog of orders (m-o-m): balance

381 .backlog of orders: balance

382.production (m-o-m): balance

383.production ( $y-0-y)$ : balance

products: balamce

386 stock of firished products (m-o-m): balance

387. stock of frished products: balance

388. expected new orders: balance

389 .scheduled production: balance

390 plarmed purchase of intem. products: balamce

391 .rum of business

392. Fim plans (cormosite index)

Labor

393. Marmower job offer index

394. persons in short working hours: women

395.persons in short working hours: men

396. persons in short working hours: women \& men $\mathrm{m}$

397.unempbyed persons: partly unempbyed per. m 398.unempbyed persons: fullly unempbyed per. $\mathrm{m}$ 399 unempbyed persons: total reg. unempbyed $\mathrm{m}$ 400.unempbyed persons: women total

401 unemployed persons: men total

402 .umemplyment rate: unerm loyment rate

403.vacancies, job offers: full-time job offers, all 404.vacancies, job offers: part-time job offers, all m

405 vacancies, job offers: total

406.job seekers: total

\section{Demand}

407. consurmption: new car registrations

408. consurmtion: ovemight stays

409 consurntion: total index, real

410. consurmtion: food \& beverages, real

411 .consurmtion: textiles \& cbthes, real

412.consurntion: other, real

413.consurmtion: uradj tom

414.consurmtion: unadj. turm., food, m-o-m, real m

415.consunmtion: unadj. tumo., textiles, m-o-m, reahm

416.consurntion: unadj. turno., other, m-o-m, real m

417. consurmtion: adj. f.tra. day, retail d-o-d, real m

418. consurmtion: adj. f.tra. day, food, d-o-d, real m

419 .consurntion: adj. f.tra. day, textiles, d-o-d, realm

420.consurntion: adj. f.tra. day, other, d-od, real m

421 .investments: utility rehick regitration $\mathrm{m}$

422.investments: irmonted capital goods m

Foreign indus trial production

423. USA : industrial production, total, excl. const. m 424. USA : industrial production, capacity utilization $\mathrm{m}$ 425.Japan: industrial production, total

425. Japan: intustrial production, cap acityutil

427. Euro Area: industrial prod., total, excl. constr. $\mathrm{m}$ 428.GB: industrial production, total, excl contr. m

429. Franoe: industrial production, total excl. constr.m

430. Italy: industrial production, total excl. oonstr. m

Foreign babormarket

431.USA: labor force

432.USA: unempbyment rate

433.USA: unempbyed persons

434.USA: persons in errybymert

435. Japan: labor force

436.Japan: unempbyed persons

437. Japan: unempbyment rate

438. Japan: vacancies, job offers

430.Japan: hours worked in marufacturine

440.GB: persons in ermloyment

441.GB: unemployed person

442.GB: unemployment rate

443. Frano: unempbyed persons

444. Frano: unempbymert rate

445. Frano: vacancies, job offers

446. Germary: unempbyed persons

447.Italy: unerryloyed persons

448.Italy: menqloymert rate

449. Italy: persons in ermloymert

$P(4)$

$P=$ periadicity $(m=$ monthily, $d=d a i l y)$

$T=$ transfomation $(0=$ original, $i=$ difference, $2=b g$ difference) 
Table 2: Properties of the Forecast Innovations for Panels $\{P(1), P(2), P(3), P(4)\}$

\begin{tabular}{|c|c|c|c|c|}
\hline$\pi^{f}$ (CPI w/o admin. prices) & $P(1)$ & $P(2)$ & $P(3)$ & $P(4)$ \\
\hline $\max _{t}\left(\max _{h}\left(\left(\left|\epsilon_{\pi^{*}, t+h \mid P j}\right|\right)\right)\right.$ & 0.3074 & 0.3720 & 0.1568 & 0.1627 \\
\hline $\min _{t}\left(\max _{h}\left(\left|\epsilon_{\pi^{*}, t+h \mid P j}\right|\right)\right)$ & 0.102 & 0.0103 & 0.0099 & 0.0039 \\
\hline $\operatorname{ave}_{\left(\max _{h}\left(\left|\epsilon_{\pi^{*}, t+h \mid P j}\right|\right)\right)}$ & 0.1374 & 0.1287 & 0.0575 & 0.0387 \\
\hline$s t d \operatorname{dev}\left(\max _{h}\left(\left|\epsilon_{\pi^{*}, t+h \mid P j}\right|\right)\right)$ & 0.0927 & 0.1002 & 0.0510 & 0.0352 \\
\hline 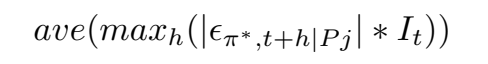 & 0.0394 & 0.0390 & 0.0135 & -0.0013 \\
\hline $\operatorname{std} \operatorname{dev}\left(\max _{h}\left(\left|\epsilon_{\pi^{*}, t+h \mid P j}\right| * I_{t}\right)\right)$ & 0.1641 & 0.1611 & 0.0768 & 0.0530 \\
\hline Direction & 0.7468 & 0.7468 & 0.7529 & $0.0000^{*}$ \\
\hline$\pi^{s}(\mathrm{CPI})$ & $P(1)$ & $P(2)$ & $P(3)$ & $P(4)$ \\
\hline $\max _{t}\left(\max _{h}\left(\left|\epsilon_{\pi, t+h \mid P j}\right|\right)\right)$ & 0.2329 & 0.2784 & 0.1297 & 0.1393 \\
\hline $\min _{t}\left(\max _{h}\left(\left|\epsilon_{\pi, t+h \mid P j}\right|\right)\right)$ & 0.0117 & 0.0101 & 0.0083 & 0.0032 \\
\hline $\operatorname{ave}_{\left(\max _{h}\left(\left|\epsilon_{\pi, t+h \mid P j}\right|\right)\right)}$ & 0.1095 & 0.1094 & 0.0492 & 0.0314 \\
\hline $\operatorname{std} \operatorname{dev}\left(\max _{h}\left(\left|\epsilon_{\pi, t+h \mid P j}\right|\right)\right)$ & 0.0666 & 0.0838 & 0.0427 & 0.0301 \\
\hline 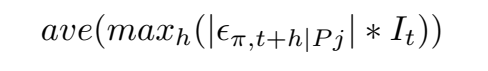 & 0.0266 & 0.0214 & 0.0097 & -0.0000 \\
\hline$s t d \operatorname{dev}\left(\max _{h}\left(\left|\epsilon_{\pi, t+h \mid P j}\right| * I_{t}\right)\right)$ & 0.1279 & 0.1385 & 0.0654 & 0.0442 \\
\hline Direction & 0.7468 & 0.7468 & $0.0000^{*}$ & $0.0000^{*}$ \\
\hline
\end{tabular}

Notes: See Table 1 for definitions of $P(1)-P(4) . I_{t}^{\pi}$ is an indicator variable +1 if $\epsilon_{\pi, t+h \mid P j}>0$; otherwise -1. For $\max _{t}\left(\max _{h}\left(\left(\left|\epsilon_{\pi^{*}, t+h \mid P j}\right|\right)\right) t=1, \cdots, 18\right.$ and $h=1, \cdots, 24 .{ }^{*}$ denotes rejection at the $5 \%$ level. Direction is a sign test between import prices and the forecast innovations for $\pi^{s}$ and $\pi^{f}$. 
Table 3: Rank Tests of the Forecast Innovations's Significance for $\pi^{f}$

\begin{tabular}{|c|c|c|c|c|}
\hline & $P(1)$ & $P(2)$ & $P(3)$ & $P(4)$ \\
\hline total & $0.0000^{*}$ & $0.0000^{*}$ & $0.0056^{*}$ & 0.2572 \\
\hline Dec 03 & $0.0000^{*}$ & $0.0000^{*}$ & $0.0000^{*}$ & 0.2951 \\
\hline Jan 04 & $0.0353^{*}$ & $0.0353^{*}$ & 0.6045 & $0.0084^{*}$ \\
\hline Feb 04 & $0.0000^{*}$ & 1.0000 & 1.0000 & $0.0353^{*}$ \\
\hline Mar 04 & $0.0000^{*}$ & $0.0000^{*}$ & 1.0000 & $0.0000^{*}$ \\
\hline Apr 04 & $0.0000^{*}$ & $0.0000^{*}$ & 0.6045 & 0.1150 \\
\hline May 04 & $0.0000^{*}$ & $0.0000^{*}$ & $0.0000^{*}$ & $0.0353^{*}$ \\
\hline Jun 04 & $0.0000^{*}$ & $0.0000^{*}$ & 0.0016 & $0.0353^{*}$ \\
\hline Jul 04 & $0.0000^{*}$ & $0.0000^{*}$ & $0.0000^{*}$ & 0.0016 \\
\hline Aug 04 & 1.0000 & $0.0084^{*}$ & $0.0000^{*}$ & $0.0000^{*}$ \\
\hline Sep 04 & $0.0000^{*}$ & $0.0000^{*}$ & $0.0084^{*}$ & $0.0002^{*}$ \\
\hline Oct 04 & $0.0000^{*}$ & $0.0000^{*}$ & 0.2951 & $0.0000^{*}$ \\
\hline Nov 04 & $0.0000^{*}$ & $0.0000^{*}$ & $0.0000^{*}$ & $0.0000^{*}$ \\
\hline Dec 04 & $0.0000^{*}$ & $0.0002^{*}$ & $0.0084^{*}$ & $0.0016^{*}$ \\
\hline Jan 05 & 0.6045 & $0.0000^{*}$ & $0.0000^{*}$ & $0.0002^{*}$ \\
\hline Feb 05 & $0.0000^{*}$ & $0.0000^{*}$ & 0.0000* & $0.0000^{*}$ \\
\hline Mar 05 & $0.0000^{*}$ & $0.0000^{*}$ & $0.0016^{*}$ & $0.0084^{*}$ \\
\hline Apr 05 & 0.6045 & 0.1150 & $0.0000^{*}$ & $0.0000^{*}$ \\
\hline May 05 & $0.0000^{*}$ & $0.0000^{*}$ & $0.0084^{*}$ & $0.0016^{*}$ \\
\hline
\end{tabular}

Notes: Statistics are $p$-values from a Wilcoxon rank test for the null that the forecast innovations for $\pi^{f}$ are insignificant. * denotes rejection of the null at the $5 \%$ critical level. See Table 1 for a description of $P(1)-P(4)$. 
Table 4: Rank Tests of the Forecast Innovations's Significance for $\pi^{s}$

\begin{tabular}{|c|c|c|c|c|}
\hline & $P(1)$ & $P(2)$ & $P(3)$ & $P(4)$ \\
\hline total & $0.0000^{*}$ & $0.0000^{*}$ & $0.0038^{*}$ & $0.0234^{*}$ \\
\hline Dec 03 & $0.0000^{*}$ & $0.0000^{*}$ & $0.0000^{*}$ & 0.2951 \\
\hline Jan 04 & 0.1150 & $0.0353^{*}$ & $0.6045^{*}$ & 0.2950 \\
\hline Feb 04 & $0.0000^{*}$ & $0.6045^{*}$ & 1.0000 & $0.0353^{*}$ \\
\hline Mar 04 & $0.0000^{*}$ & $0.0000^{*}$ & 1.0000 & 0.6044 \\
\hline Apr 04 & $0.0000^{*}$ & $0.0000^{*}$ & $0.6045^{*}$ & 0.2951 \\
\hline May 04 & $0.0000^{*}$ & $0.0000^{*}$ & $0.0000^{*}$ & $0.0000^{*}$ \\
\hline Jun 04 & $0.0000^{*}$ & $0.0000^{*}$ & $0.0084^{*}$ & 0.6045 \\
\hline Jul 04 & $0.0000^{*}$ & $0.0353^{*}$ & $0.0000^{*}$ & 0.1145 \\
\hline Aug 04 & 1.0000 & $0.0002^{*}$ & $0.0000^{*}$ & $0.0000^{*}$ \\
\hline Sep 04 & $0.0000^{*}$ & $0.0000^{*}$ & $0.0016^{*}$ & $0.0016^{*}$ \\
\hline Oct 04 & $0.0000^{*}$ & $0.0000^{*}$ & 0.6044 & $0.0000^{*}$ \\
\hline Nov 04 & $0.0000^{*}$ & $0.0000^{*}$ & $0.0000^{*}$ & $0.0000^{*}$ \\
\hline Dec 04 & $0.0000^{*}$ & $0.0002^{*}$ & $0.0353^{*}$ & $0.0084^{*}$ \\
\hline Jan 05 & 0.2951 & $0.0000^{*}$ & $0.0000^{*}$ & $0.0084^{*}$ \\
\hline Feb 05 & $0.0000^{*}$ & $0.0000^{*}$ & $0.0000^{*}$ & $0.0000^{*}$ \\
\hline Mar 05 & $0.0000^{*}$ & $0.0000^{*}$ & $0.0000^{*}$ & $0.0016^{*}$ \\
\hline Apr 05 & $0.0016^{*}$ & $0.0000^{*}$ & $0.0000^{*}$ & $0.0000^{*}$ \\
\hline May 05 & $0.0000^{*}$ & $0.0000^{*}$ & $0.0084^{*}$ & $0.0016^{*}$ \\
\hline
\end{tabular}

Notes: Statistics are $p$-values from a Wilcoxon rank test for the null that the forecast innovations for $\pi^{s}$ are insignificant. * denotes rejection of the null at the $5 \%$ critical level. See Table 1 for a description of $P(1)-P(4)$. 
Table 5: Granger Non Causality Tests of Inflation on the Pass-Through

\begin{tabular}{ccccc}
\hline & $P(1)$ & $P(2)$ & $P(3)$ & $P(4)$ \\
\hline CPI & & & & \\
F-stat & 0.2573 & 0.22221 & 0.04000 & 0.1228 \\
$p$-value & 0.7777 & 0.8043 & 0.9610 & 0.8857
\end{tabular}

CPI without Ad. Prices

$\begin{array}{lllll}\text { F-stat } & 0.3517 & 0.2794 & 0.1079 & 0.0523 \\ p \text {-value } & 0.7111 & 0.7615 & 0.8987 & 0.9493\end{array}$

Notes: The Granger regressions are with 2 lags for 16 observations. 
Table 6: Rank Tests of the Forecast Innovations between $\pi^{f}$ and $\pi^{s}$

\begin{tabular}{|c|c|c|c|c|}
\hline & $P(1)$ & $P(2)$ & $P(3)$ & $P(4)$ \\
\hline total & 0.2078 & 0.3255 & 0.5136 & 0.3196 \\
\hline Dec 03 & 0.3808 & $0.0000^{*}$ & $0.0266^{*}$ & 0.0779 \\
\hline Jan 04 & 0.3274 & 0.6876 & 0.6725 & 0.1460 \\
\hline Feb 04 & 0.2240 & 0.7649 & 1.0000 & 0.8286 \\
\hline Mar 04 & 0.1460 & 0.1578 & 0.6876 & $0.0002^{*}$ \\
\hline Apr 04 & 0.1975 & 0.1768 & 1.0000 & 0.6725 \\
\hline May 04 & 0.1904 & 0.1147 & $0.0080^{*}$ & 0.8286 \\
\hline Jun 04 & $0.0466^{*}$ & 0.5990 & 0.2611 & 0.1195 \\
\hline Jul 04 & 0.1975 & 0.1404 & 0.2700 & 0.3921 \\
\hline Aug 04 & 0.7807 & 0.6876 & 0.7029 & 0.1578 \\
\hline Sep 04 & 0.7966 & 0.9753 & 0.4273 & 0.2700 \\
\hline Oct 04 & 0.0779 & 0.1245 & 0.2610 & 0.4394 \\
\hline Nov 04 & $0.0000^{*}$ & $0.0001^{*}$ & 0.3173 & 0.2122 \\
\hline Dec 04 & 0.1703 & 0.1975 & 0.8447 & 0.5848 \\
\hline Jan 05 & 0.5430 & 0.7182 & 0.0889 & 0.3376 \\
\hline Feb 05 & 0.5028 & 0.4037 & 0.4517 & $0.0215^{*}$ \\
\hline Mar 05 & 0.1703 & 0.1404 & 0.0744 & 1.0000 \\
\hline Apr 05 & $0.0240^{*}$ & $0.0000^{*}$ & 0.4037 & 0.1055 \\
\hline May 05 & 0.2700 & 0.1768 & 0.3173 & 0.9097 \\
\hline
\end{tabular}

Notes: Statistics are $p$-values from a Wilcoxon rank test for the null: $\epsilon_{\pi^{s}, t+h \mid} P(k)_{j, t}=\epsilon_{\pi^{f}, t+h \mid P(k)_{j, t}}$.

* denotes rejection of the null at the $5 \%$ critical level. See Table 1 for a description of $P(1)-P(4)$. 
Table 7: Rank Tests of the Forecast Innovations's for $\pi^{f}$ based on Information Sets

\begin{tabular}{|c|c|c|c|c|}
\hline & $P(1)$ vs $P(2)$ & $P(1)$ vs $P(3)$ & $P(1)$ vs $P(4)$ & $P(3)$ vs $P(4)$ \\
\hline total & 0.5407 & $0.0000^{*}$ & $0.0000^{*}$ & $0.0008^{*}$ \\
\hline Dec 03 & $0.0000^{*}$ & $0.0000^{*}$ & $0.0000^{*}$ & $0.0000^{*}$ \\
\hline Jan 04 & $0.0182^{*}$ & $0.0006^{*}$ & $0.0122^{*}$ & 0.5707 \\
\hline Feb 04 & $0.0009^{*}$ & $0.0002^{*}$ & $0.0328^{*}$ & $0.0008^{*}$ \\
\hline Mar 04 & 0.2122 & $0.0000^{*}$ & $0.0000^{*}$ & $0.0011^{*}$ \\
\hline Apr 04 & 0.2199 & $0.0000^{*}$ & $0.0000^{*}$ & 0.0779 \\
\hline May 04 & $0.0172^{*}$ & $0.0000^{*}$ & $0.0000^{*}$ & 0.8934 \\
\hline Jun 04 & 0.3922 & $0.0000^{*}$ & $0.0000^{*}$ & $0.0001^{*}$ \\
\hline Jul 04 & 0.4213 & 0.1640 & $0.0000^{*}$ & $0.0000^{*}$ \\
\hline Aug 04 & 0.3697 & $0.0004^{*}$ & $0.0444^{*}$ & $0.0154^{*}$ \\
\hline Sep 04 & 0.1768 & $0.0163^{*}$ & $0.0000^{*}$ & $0.0000^{*}$ \\
\hline Oct 04 & 1.0000 & $0.0000^{*}$ & $0.0019^{*}$ & $0.0004^{*}$ \\
\hline Nov 04 & 0.2567 & $0.0000^{*}$ & $0.0000^{*}$ & $0.0477^{*}$ \\
\hline Dec 04 & 0.5848 & $0.0029^{*}$ & 0.1245 & 0.0513 \\
\hline Jan 05 & $0.0010^{*}$ & $0.0001^{*}$ & 0.0650 & $0.0000^{*}$ \\
\hline Feb 05 & 0.2977 & 0.6575 & 0.2277 & $0.0001^{*}$ \\
\hline Mar 05 & 0.3588 & $0.0000^{*}$ & $0.0049^{*}$ & $0.0040^{*}$ \\
\hline Apr 05 & 0.0680 & 0.4642 & 0.7182 & 0.7029 \\
\hline May 05 & 0.1100 & $0.0081^{*}$ & $0.0001^{*}$ & 0.1100 \\
\hline
\end{tabular}

Notes: Statistics are $p$-values from a Wilcoxon rank test for the null: $\epsilon_{\pi^{f}, t+h \mid P(k)}=\epsilon_{\pi^{f}, t+h \mid P(l)}$ for $k \neq l$.

* denotes rejection of the null at the $5 \%$ critical level. See Table 1 for a description of $P(1)-P(4)$. 
Table 8: Rank Tests of the Forecast Innovations's for $\pi^{s}$ based on Information Sets

\begin{tabular}{|c|c|c|c|c|}
\hline & $P(1)$ vs $P(2)$ & $P(2)$ vs $P(3)$ & $P(2)$ vs $P(4)$ & $P(3)$ vs $P(4)$ \\
\hline total & 0.7416 & $0.0014^{*}$ & $0.0000^{*}$ & $0.0331^{*}$ \\
\hline Dec 03 & 0.1404 & $0.0000^{*}$ & $0.0000^{*}$ & 0.3273 \\
\hline Jan 04 & $0.0000^{*}$ & 0.6134 & $0.0000^{*}$ & 0.4095 \\
\hline Feb 04 & 0.7182 & $0.0190 *$ & $0.0076^{*}$ & $0.0000^{*}$ \\
\hline Mar 04 & 0.3377 & $0.0000^{*}$ & $0.0091^{*}$ & $0.0000 *$ \\
\hline Apr 04 & $0.0063^{*}$ & $0.0000^{*}$ & $0.0000^{*}$ & $0.0000^{*}$ \\
\hline May 04 & 0.5707 & $0.0000^{*}$ & 0.1147 & $0.0364 *$ \\
\hline Jun 04 & 0.3377 & $0.0000 *$ & $0.0109^{*}$ & 0.0680 \\
\hline Jul 04 & 0.8609 & 0.5707 & $0.0109 *$ & $0.0000^{*}$ \\
\hline Aug 04 & 0.2358 & $0.0000^{*}$ & $0.0000^{*}$ & $0.0002^{*}$ \\
\hline Sep 04 & 0.2440 & $0.0005^{*}$ & $0.0000^{*}$ & $0.0071^{*}$ \\
\hline Oct 04 & 0.3481 & $0.0002^{*}$ & $0.0001^{*}$ & $0.0000^{*}$ \\
\hline Nov 04 & 0.1975 & $0.0489^{*}$ & $0.0000 *$ & $0.0063^{*}$ \\
\hline Dec 04 & $0.0145^{*}$ & $0.0027^{*}$ & $0.0004^{*}$ & 0.5027 \\
\hline Jan 05 & 0.2358 & 0.6876 & $0.0002^{*}$ & 0.1055 \\
\hline Feb 05 & 0.2611 & $0.0122^{*}$ & $0.0000^{*}$ & 0.6876 \\
\hline Mar 05 & $0.0031^{*}$ & $0.0000^{*}$ & $0.0145^{*}$ & $0.0007^{*}$ \\
\hline Apr 05 & $0.0489^{*}$ & $0.0000^{*}$ & $0.0466^{*}$ & 0.8609 \\
\hline May 05 & 0.6576 & $0.0008^{*}$ & $0.0000^{*}$ & $0.0000^{*}$ \\
\hline
\end{tabular}

Notes: Statistics are $p$-values from a Wilcoxon rank test for the null: $\epsilon_{\pi^{s}, t+h \mid P(k)}=\epsilon_{\pi^{s}, t+h \mid P(l)}$ for $k \neq l$.

* denotes rejection of the null at the $5 \%$ critical level. See Table 1 for a description of $P(1)-P(4)$. 
Figure 1: Swiss Prices 1993:5 to 2005:4

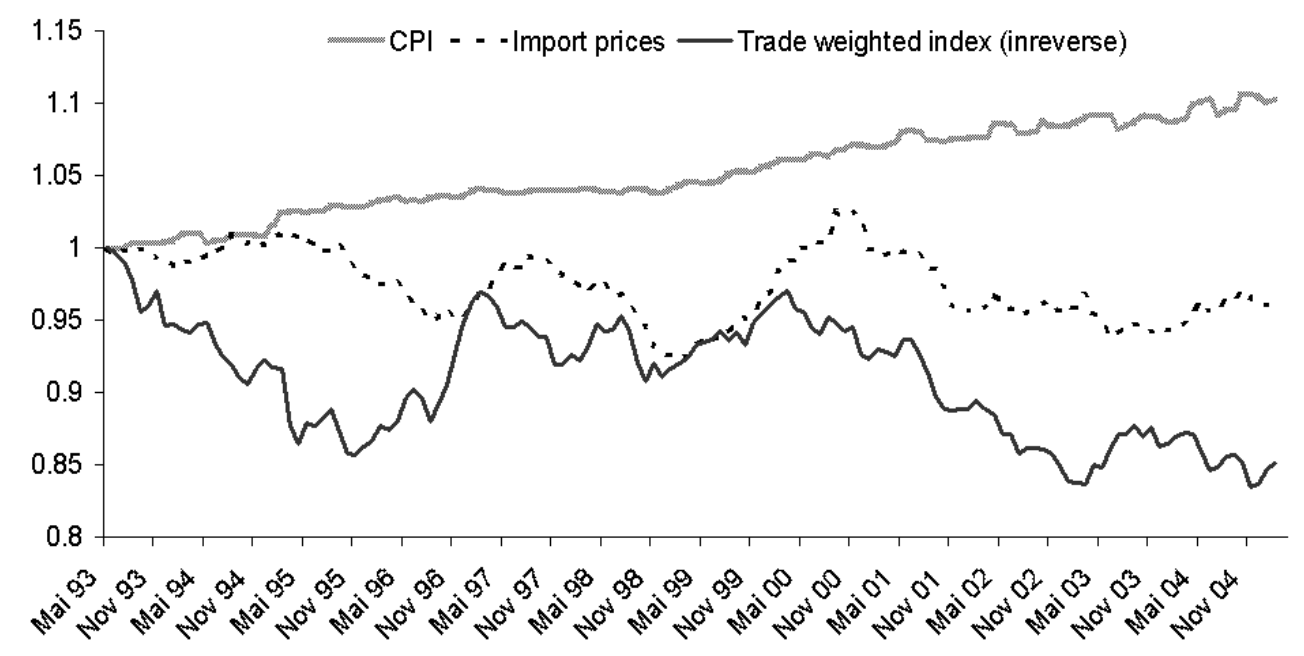


Figure 2: Swiss Monthly Inflation 2003:11 to 2005:4

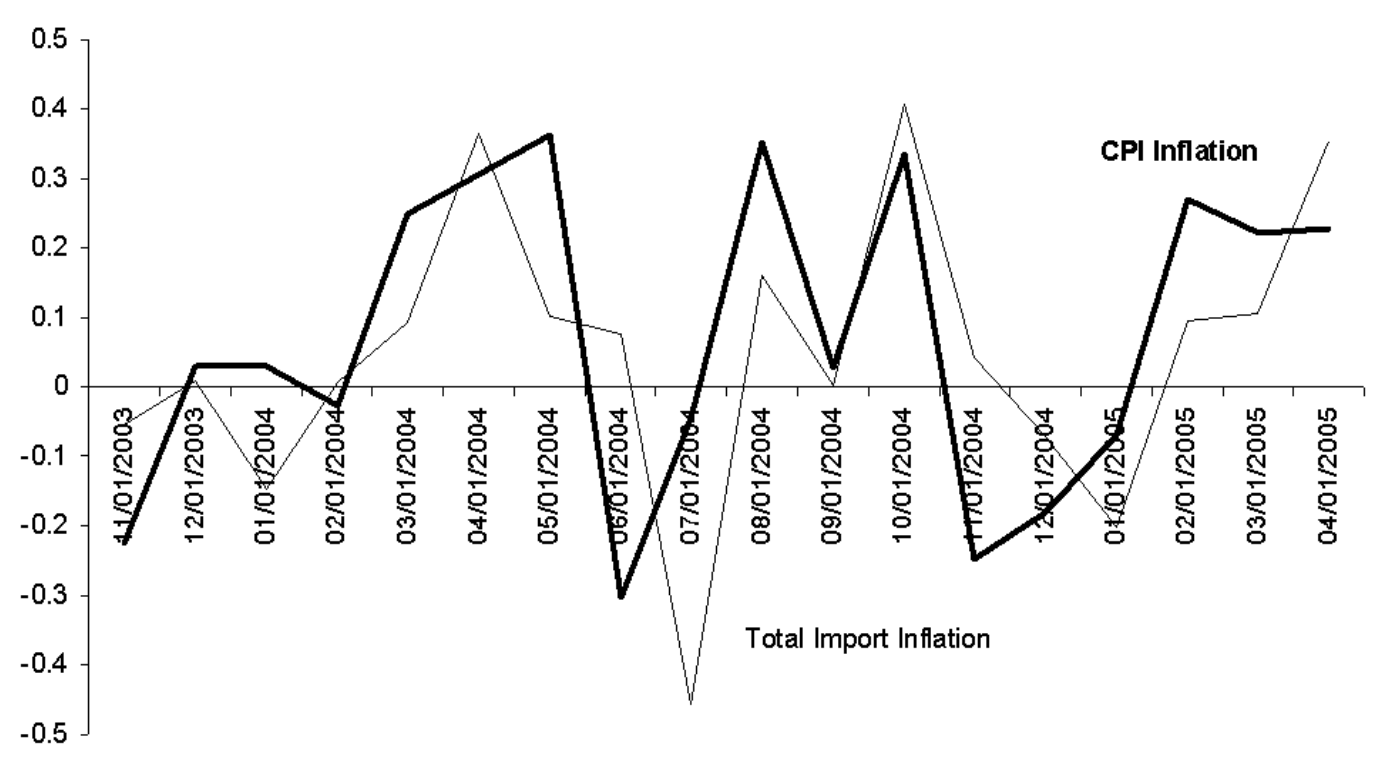


Figure 3: $\mathrm{CPI}$ and $\mathrm{CPI}$ minus Administered Prices

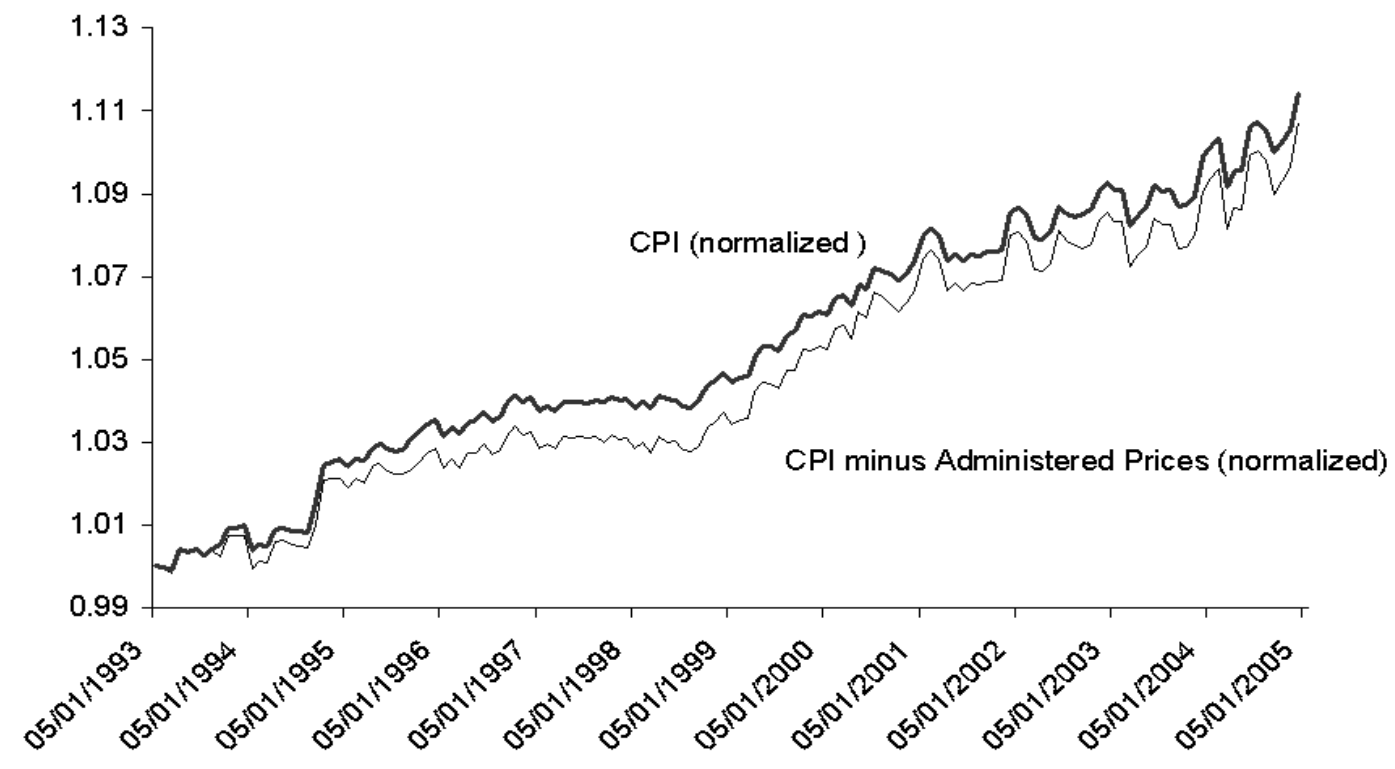


Figure 4: Monthly Inflation (2003:11 to 2005:4)

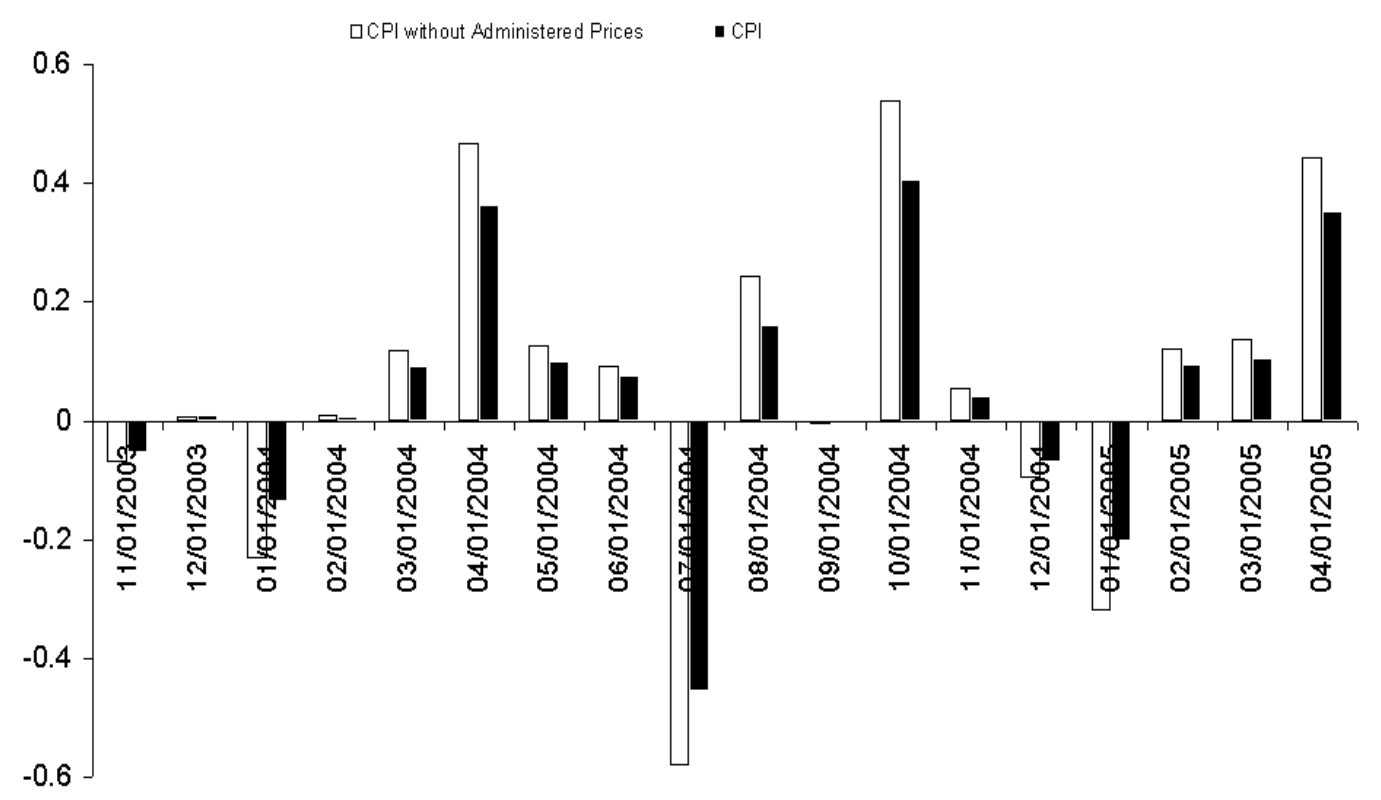


Figure 5:

Max, Min, and Ave Forecast Innovations for $\pi^{f}$ (CPI w/o admin. prices) and $\pi^{s}$ (CPI)

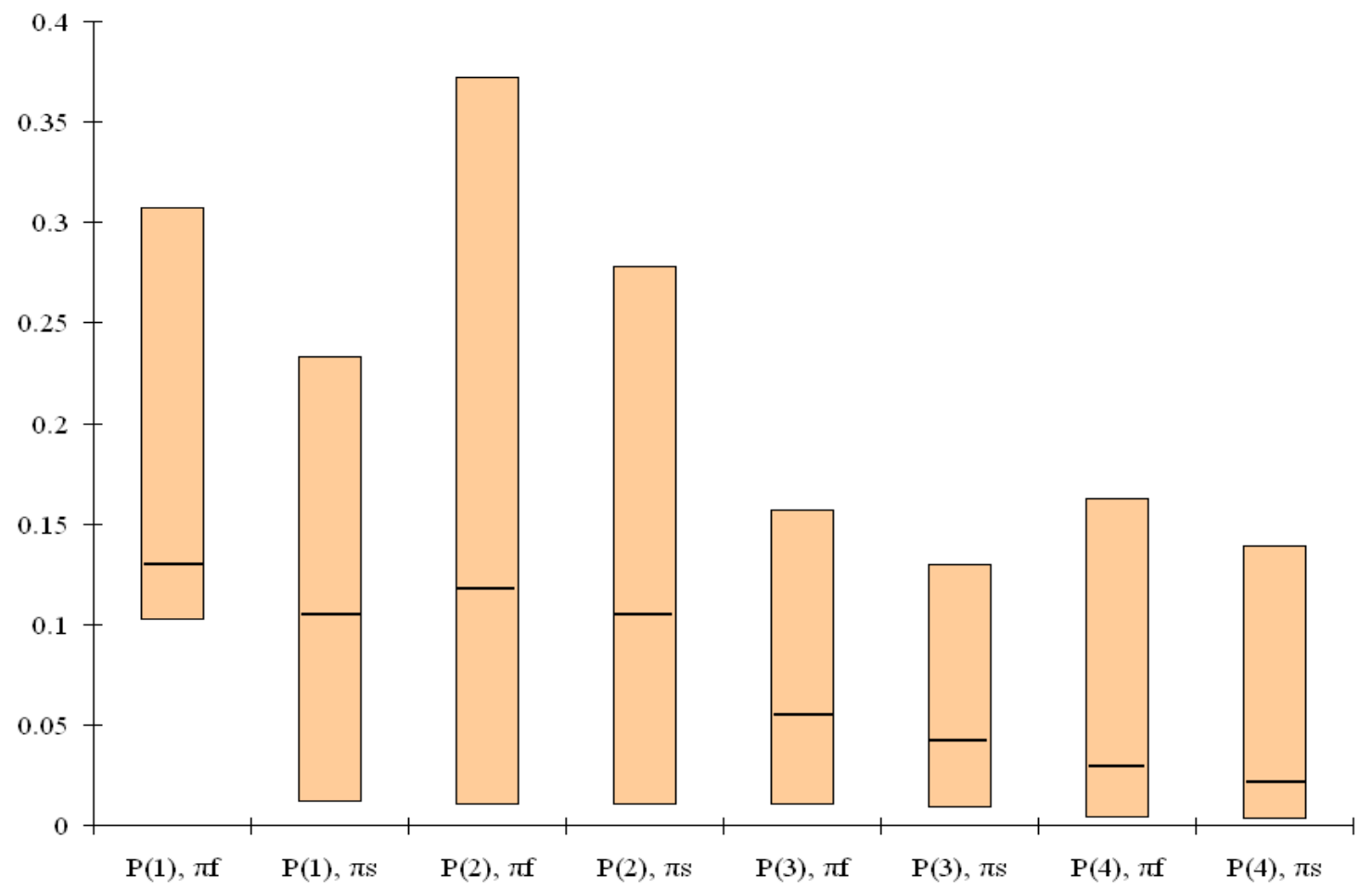

Notes: Box upper bound $=$ max of innovation, box lower bound $=$ min of innovation, black line within the box $=$ average of innovations. Figures taken from Table 2. 
Figure 6: Pass-Through versus Lag Length

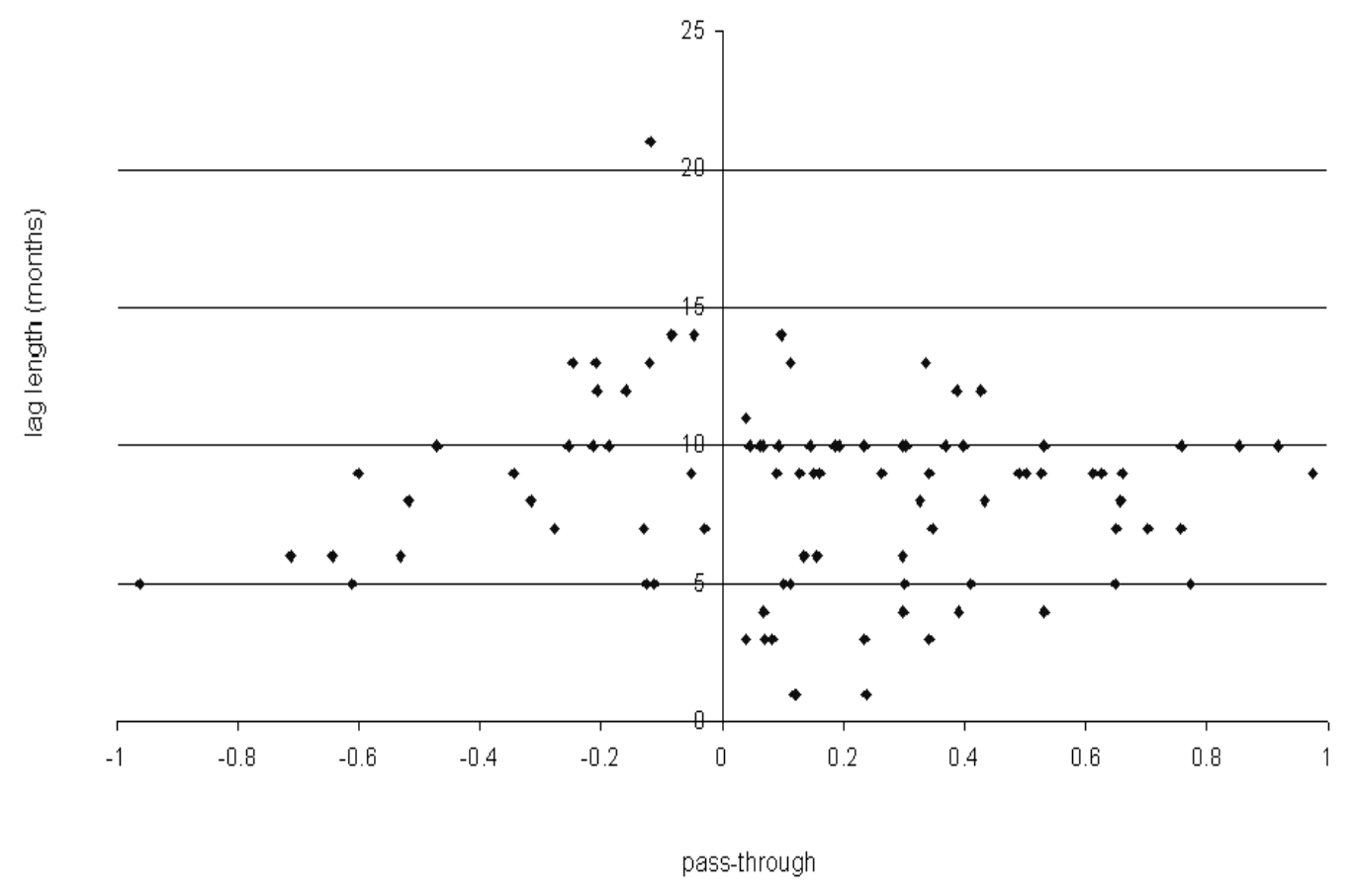




\section{Swiss National Bank Working Papers published since 2004:}

2004-1 Samuel Reynard: Financial Market Participation and the Apparent Instability of Money Demand

2004-2 Urs W. Birchler and Diana Hancock: What Does the Yield on Subordinated Bank Debt Measure?

2005-1 Hasan Bakhshi, Hashmat Khan and Barbara Rudolf: The Phillips curve under state-dependent pricing

2005-2 Andreas M. Fischer: On the Inadequacy of Newswire Reports for Empirical Research on Foreign Exchange Interventions

2006-1 Andreas M. Fischer: Measuring Income Elasticity for Swiss Money Demand: What do the Cantons say about Financial Innovation?

2006-2 Charlotte Christiansen and Angelo Ranaldo: Realized Bond-Stock Correlation: Macroeconomic Announcement Effects

2006-3 Martin Brown and Christian Zehnder: Credit Reporting, Relationship Banking, and Loan Repayment

2006-4 Hansjörg Lehmann and Michael Manz: The Exposure of Swiss Banks to Macroeconomic Shocks - an Empirical Investigation

2006-5 Katrin Assenmacher-Wesche and Stefan Gerlach: Money Growth, Output Gaps and Inflation at Low and High Frequency: Spectral Estimates for Switzerland

2006-6 Marlene Amstad and Andreas M. Fischer: Time-Varying Pass-Through from Import Prices to Consumer Prices: Evidence from an Event Study with Real-Time Data 
Swiss National Bank Working Papers are also available at www.snb.ch, section Publications/Research Subscriptions or individual issues can be ordered at Swiss National Bank, Fraumünsterstrasse 8, CH-8022 Zurich, fax+41 4463181 14, E-mail library@snb.ch 